\title{
Aquaculture The Thread of the Emerging Resiliency of Coastal Area in Indramayu
}

\author{
Assy Saffa SAKINAH, Center of Urban Design Studies, Indonesia \\ Dionisius BRIANANTO, Center of Urban Design Studies, Indonesia \\ Riardy SULAIMAN, Center of Urban Design Studies, Indonesia
}

\begin{abstract}
Projected as the future Minapolitan area of West Java by Indonesia's Ministry of Marine Affairs and Fisheries, Indramayu Regency possesses an abundance of coastal resources such as fisheries, mangroves \& aquaculture. Yet among 309 villages in Indramayu, 46 are stated to be underdeveloped in 2019, making Indramayu Regency the lowest five among West Java in its Human Development Index. These underdeveloped villages are mostly housing families whose daily earnings are solely based on agriculture or/and fisheries activities located in the coastal part of Indramayu. The critical urgency of economic resilience supported by these natural resources is highlighted by The Spatial and Regional Planning of Indramayu Regency 2011-2031, stating Indramayu as the Regency Strategic Area in order to anchor further development agenda that will secure the wellbeing of its people. This study investigates possibilities in integrating the use of space and design of everyday infrastructure (specifically aquacultures) through sustainable coastal development to serve better resiliency provisions for the local economy and disaster mitigation as an anticipative response to the abrasion risk exposed to coastal Indramayu. The research will be carried out through qualitative and exploratory study starting with the case study done in Karangsong Village as the foundation that will be followed up by an analytical framework evaluating schemes of urban aquaculture facets explored by Grit Buergow in 2014. The explorative evaluation will revolve around the resiliency impacts of the water-living culture, water-farming culture, and water-wellbeing culture as the Water Sensitive Urban Design (WSUD) approach to review the readiness of Karangsong Village to adopt the mentioned coastal development. The results should assist stakeholders in regulating urban planning scenarios that enhance resiliency and the circular system of aquaculture cultivation in those underdeveloped villages along with the involvement of communities, which many of whom struggle to maintain reasonable livelihoods. The formulated urban planning scenario will be generally applicable up to the extent of both statutory planning (Building and Environmental Planning) and non-statutory planning (Masterplan) as long as collaborative and participatory approaches are conducted with the affiliated stakeholders.
\end{abstract}

\section{Keywords}

Aquaculture, Resiliency, Coastal Development, Aquatecture, Aquapuncture 


\section{Introduction}

\subsection{Aim and Scope}

This paper investigates the possibilities in integrating space and design of everyday infrastructures supporting the aquaculture activities in Karangsong Village, Indramayu, Indonesia. The existing aquaculture activities in the area might be capable of being developed as a more integrated sustainable coastal development, required to serve better resiliency provisions for the local economy and disaster mitigation. The knowledge aims to improve the quality of lives of the people in Indramayu whose economy was considered lowest in Western Java. The study is beneficial for supporting documents required for both official statutory and non-statutory planning in order to take a more concrete steps in alleviating poverties and underdevelopments.

\subsection{Fisheries and Tourism as Economical Resiliency}

Marine and aquaculture fisheries collectively produced 30.8 million tonnes of aquatic animals in 2018, equivalently worth USD 106.5 billion (FAO UN, 2020). In this case, aquaculture fisheries plays a crucial role in the livelihoods of coastal communities in developing countries, along in their employment and local economics. The demand of fish consumption has grown and been fuelled by urbanization and expansion of fish-consuming middle class in developing countries.

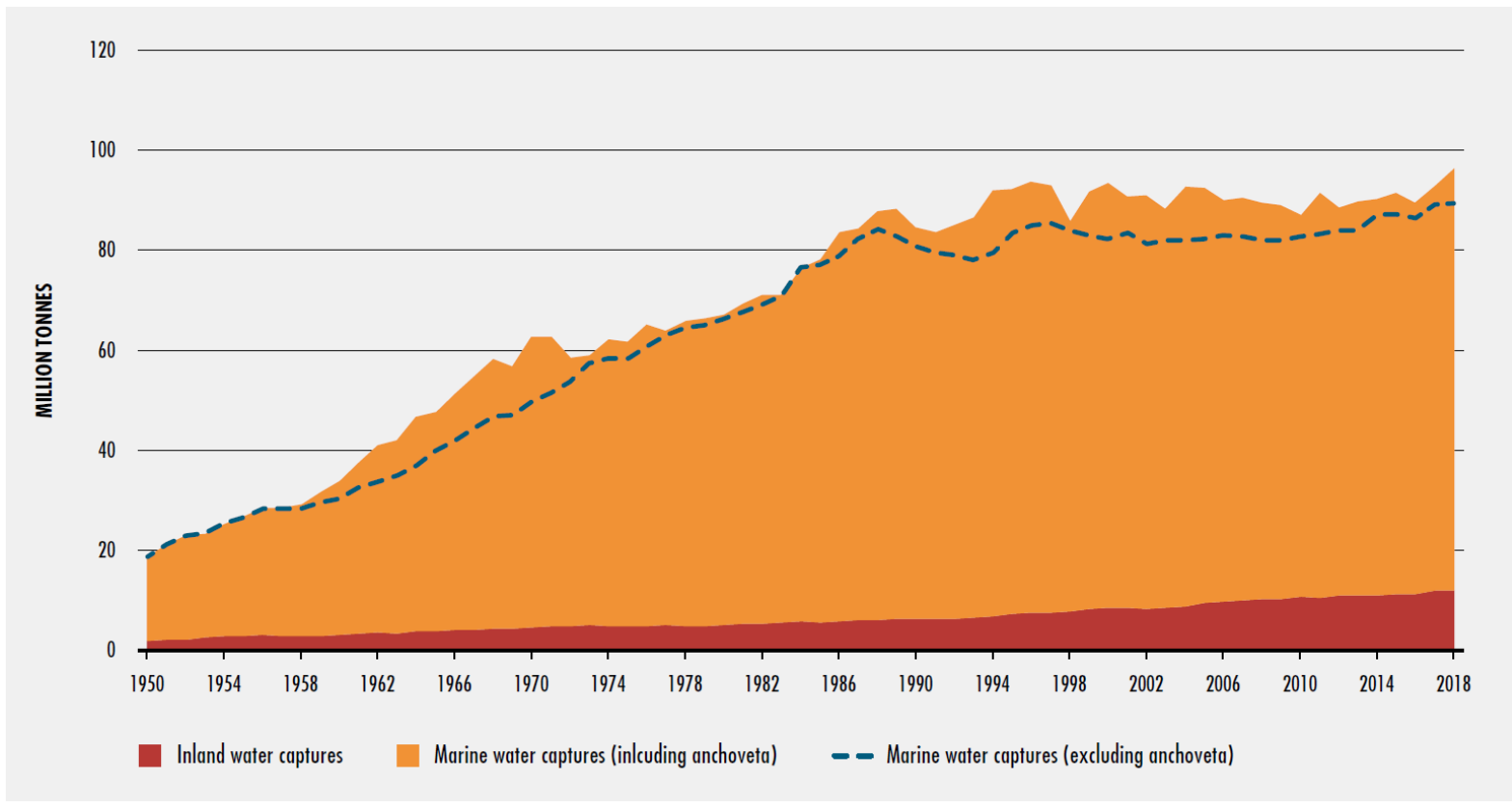

Figure 1. Trends in Global Capture. Source: Food and Agriculture Organization (FAO) of United Nations (UN)

Fish globally provided more than 3 billion people, reaching 50 percent of their average per capita intake of animal proteins in developing countries such as Bangladesh, Cambodia, Indonesia, and several small island developing States (SIDS), making Indonesia the second most productive country in the world after China in their 7 percent of global productivity of fisheries. Not only its capture and production, fish and fishery products remain to be some of the most traded food commodities in the world. Not only have the expansion in exports, fisheries in Indonesia also helped provide important source of nutrition, affordable for populations that are dependent on a narrow range of staple foods. 


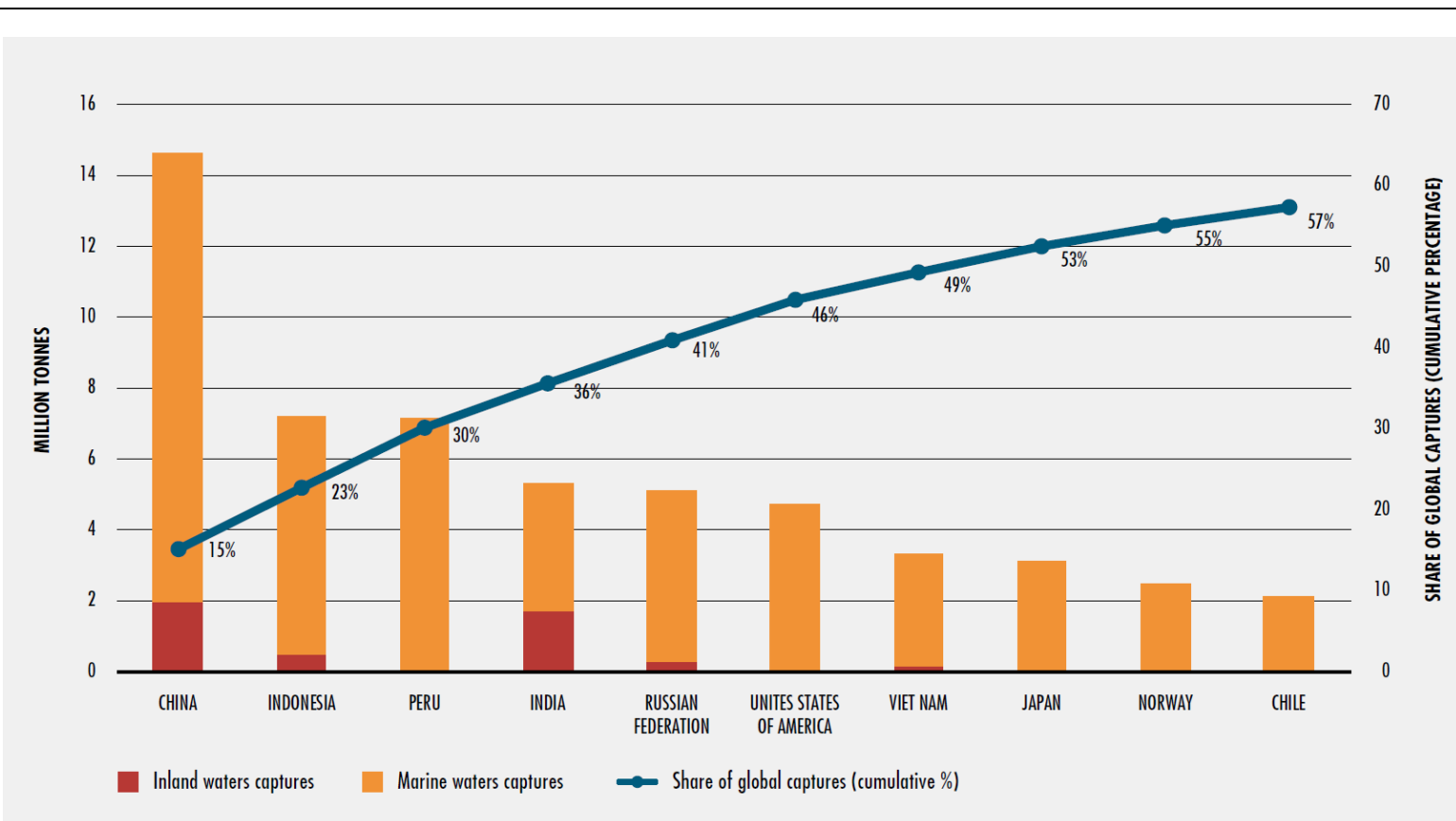

Figure 2. Top Ten Global Capture Producers. Source: Food and Agriculture Organization (FAO) of United Nations (UN)

\begin{tabular}{|c|c|c|c|c|c|c|}
\hline & 1995 & 2000 & 2005 & 2010 & 2015 & 2018 \\
\hline & \multicolumn{6}{|c|}{ (thousands) } \\
\hline \multicolumn{7}{|c|}{ Fisheries and aquaculture } \\
\hline Africa & 2812 & 3348 & 3925 & 4483 & 5067 & 5407 \\
\hline Americas & 2072 & 2239 & 2254 & 2898 & 3193 & 2843 \\
\hline Asia & 31632 & 40434 & 44716 & 49427 & 49969 & 50385 \\
\hline Europe & 476 & 783 & 658 & 648 & 453 & 402 \\
\hline Oceania & 466 & 459 & 466 & 473 & 479 & 473 \\
\hline Total & 37456 & 47263 & 52019 & 57930 & 59161 & 59509 \\
\hline \multicolumn{7}{|l|}{ Fisheries } \\
\hline Africa & 2743 & 3247 & 3736 & 4228 & 4712 & 5021 \\
\hline Americas & 1793 & 1982 & 2013 & 2562 & 2816 & 2455 \\
\hline Asia & 24205 & 28079 & 29890 & 31517 & 30436 & 30768 \\
\hline Europe & 378 & 679 & 558 & 530 & 338 & 272 \\
\hline Oceania & 460 & 451 & 458 & 467 & 469 & 460 \\
\hline Total & 29579 & 34439 & 36655 & 39305 & 38771 & 38976 \\
\hline \multicolumn{7}{|c|}{ Aquaculture } \\
\hline Africa & 69 & 100 & 189 & 255 & 355 & 386 \\
\hline Americas & 279 & 257 & 241 & 336 & 377 & 388 \\
\hline Asia & 7426 & 12355 & 14826 & 17910 & 19533 & 19617 \\
\hline Europe & 98 & 104 & 100 & 118 & 115 & 129 \\
\hline Oceania & 6 & 8 & 8 & 6 & 10 & 12 \\
\hline Total & 7878 & 12825 & 15364 & 18625 & 20390 & 20533 \\
\hline
\end{tabular}

NOTE: The regional and global totals have been adjusted in some cases as a result of extended work on the dataset to revise historical data and improve the methodologies applied for estimations.

Figure 3. World Employment for Fishers and Fish Farmers by Region. Source: Food and Agriculture Organization (FAO) of United Nations (UN) 
As the majority of coastal communities in Karangsong Village, fishermen rely their earnings on the aquaculture production, hence developing aquaculture infrastructure would improve their economic resiliency. Multiple ways in cultivating aquaculture infrastructure in order to provide economic service have emerged, including the mangrove-associated aquaculture as a potential of coastal ecotourism. Awareness of the mangrove ecotourism has increased in Indonesia, projecting a larger and wider opportunities in providing economical resiliency. Integrating mangrove and aquaculture as one complementary ecosystem has proven to not only be aesthetically bettering the coastal landscape, but also creating a sustainable resilient mangrove greenbelts while the aquaculture productivity is enhanced as proven by Associated Mangrove Aquaculture System (AMA) (Wetlands Organization, 2020).

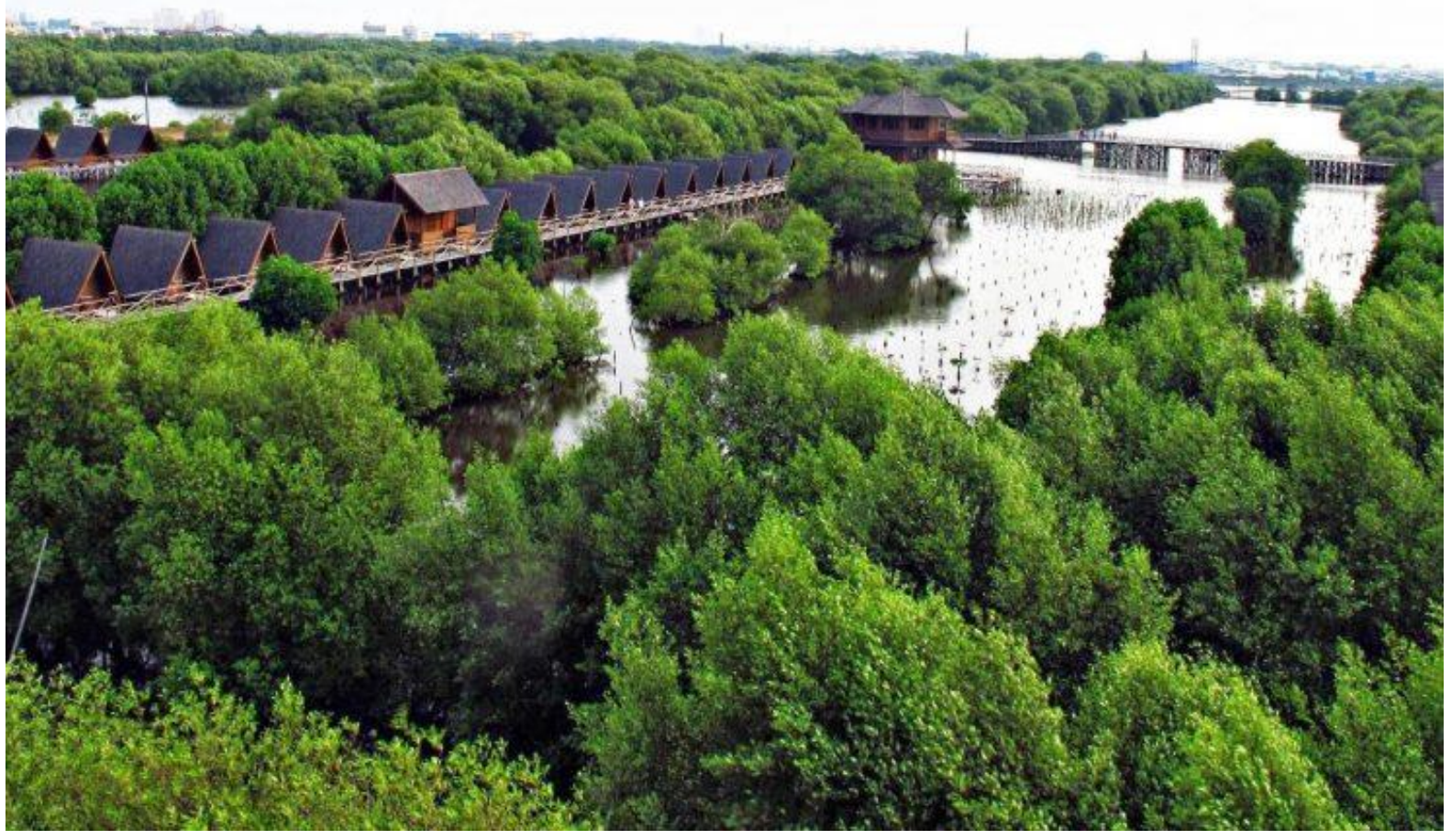

Figure 4. Mangrove Ecotourism in Jakarta, Indonesia. Source: Berdikari Online.

\subsection{Coastal Resiliency \& Aquaculture as the Sustainable Coastal Development}

Urban coastlines have always been prone to physical disturbances affecting the resiliency of the area. Common disturbances that emerge as the sea level rises are found -but not limited-to mostly be the risk of abrasion, tidal waves, and flood. The awareness of the risk has been widely acquired that the notion of coastal resiliency covering the integration between infrastructure, landscape and ecosystems that can withstand and recover from these disturbances has emerged as a guiding principle of urban waterfront development. (Ezban, 2020). The instruction to adapt with transformative capacity rather than to resist change (Lister, 2015) is chosen to be the stance for defining resiliency in this paper.

\section{D isocarp}




\section{Context}

\subsection{Indramayu as Prospective Strategic Minapolitan Area}

Indramayu is a regency in West Java province which was appointed by the Ministry of Marine Affairs and Fisheries of Indonesia as the location of Minapolitan Area. It has around 1,8 million population with 204.011 hectares area size with 31 districts, and 309 villages which is characterized by the coastal life resources such as fisheries, aquaculture, and mangrove conservation. Minapolitan is a concept of marine and fisheries development based on the economy management of an area, as tool to improve the marine and fisheries economic development. It is developed through increasing efficiency and optimizing comparative and competitive advantages. The strategies of the Minapolitan development are based on the existing activities of pre-production, production, processing, and marketing activities as well as other services, which are carried out in an integrated, holistic, and sustainable manner (KKP, 2013).

Since the $17^{\text {th }}$ century, Indramayu exists as one of the important harbours owned by Sunda Kingdom. It used Cimanuk River as the way to distribute goods and market (Nurlelasari, 2016). The coastal city grew as an administrative ruled the market between local and outside trader. Furthermore, the road and the city facilities sprawled outside the city centre followed by market purposes (Kuntowijoyo, 2003: 61-62). Since the Dutch colonization in 1910, the east part of Cimanuk River still used as the more profitable land, compared to the west part. In 1925, Indramayu became an autonomous region which continuously developed. The historical archive stated Indramayu was a harbour city, where the market activities were already regulated by the local government. In the present, the fisheries harbour has strategic value for the fishermen and communities as part of their natural resource, cultural and economic values. As shown by the water source of PDAM, Indramayu uses surface water from Cimanuk River, Cipelang, Cipanas, and Wanguk Irrigation Channel, and deep groundwater. However, dry season becomes an obstacle because Cimanuk River and the existing irrigation canals decrease in volume of water needs.

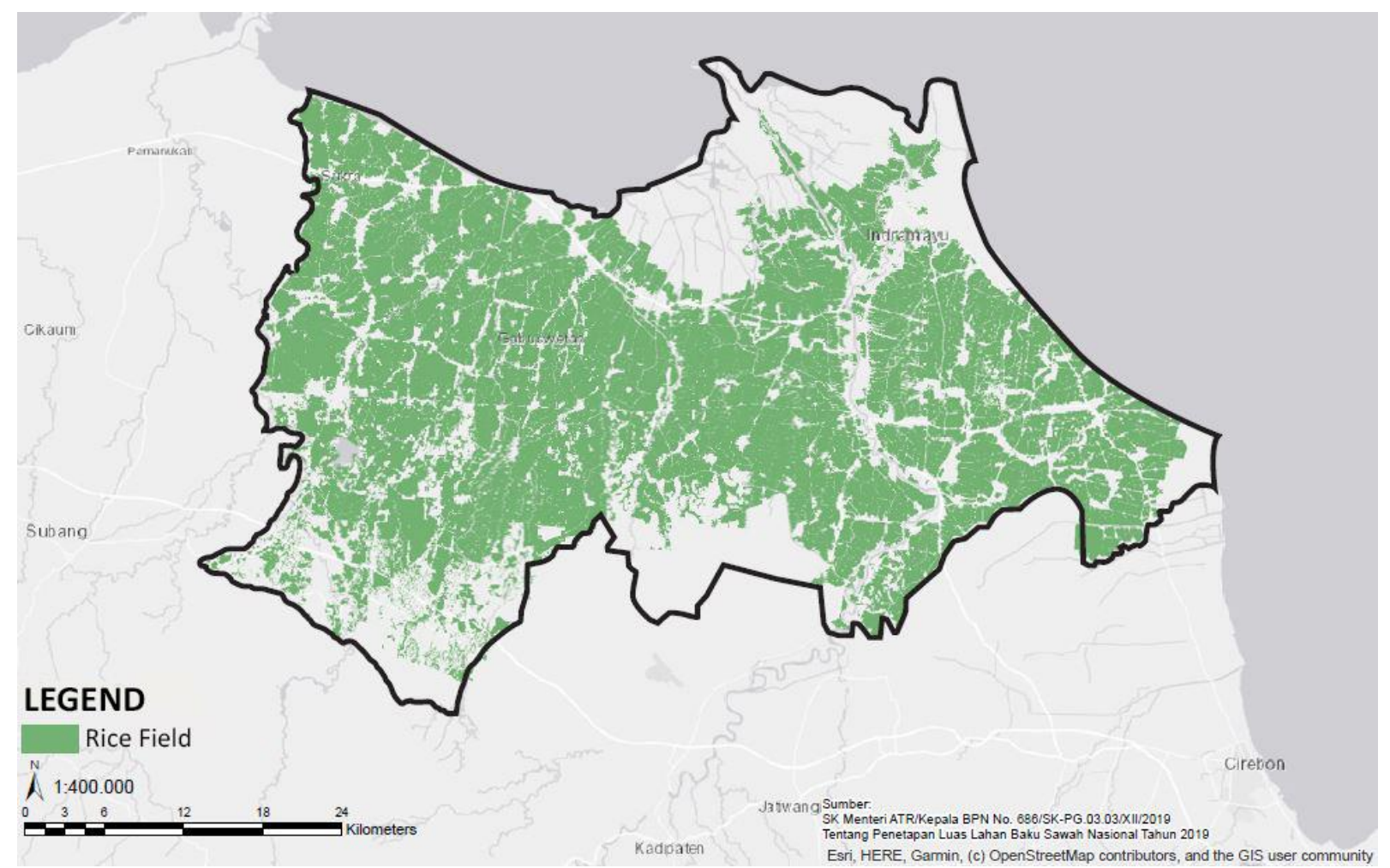

Figure 5. Rice Field Resource in Indramayu. Source: The Indonesian Ministry of Agrarian Affairs and Spatial Planning 2018. 
Despite its potential, among 309 villages, 46 are stated to be underdeveloped in 2019, making Indramayu Regency the lowest five among West Java Province in its Human Development Index. In 2018, the Indonesia Central Bureau of Statistics data showed that Indramayu has 66,36 of Human Development Index, which lower than the average of West Java Province Index in 71,30. The underdeveloped villages are mostly settled by housing families, whose daily earnings are solely based on agriculture or and fisheries activities located in the coastal part of Indramayu. The economic resilience condition becomes an issue yet supported by the natural resources' potential. It is highlighted on The Spatial and Regional Planning of Indramayu Regency 2011-2031, stating Indramayu as the Regency Strategic Area to improve and utilize further development agenda that able to secure the wellbeing of its inhabitants.

\subsection{Aquaculture in Karangsong Village, Indramayu}

According to the FAO, aquaculture includes both an enhancement fish production, through breeding or feeding practices, as well as the stock ownership being cultivated. The global aquaculture growth rapidly in the last fifty years. The production of fish or human consumption in 2019 is the fastest growing food production sector in the world (Ezban, 2020). Michael Ezban (2020) also mentioned that aquaculture landscapes are located geographically, shaped in a range encounter between humans and fish, while the production is informed by the variable relations between the species that cohabit them. The exploratory research also focuses on the three characteristic facets (Buergow, 2014) of Karangsong aquaculture; water-farming culture, water-living culture, and water-wellbeing culture.

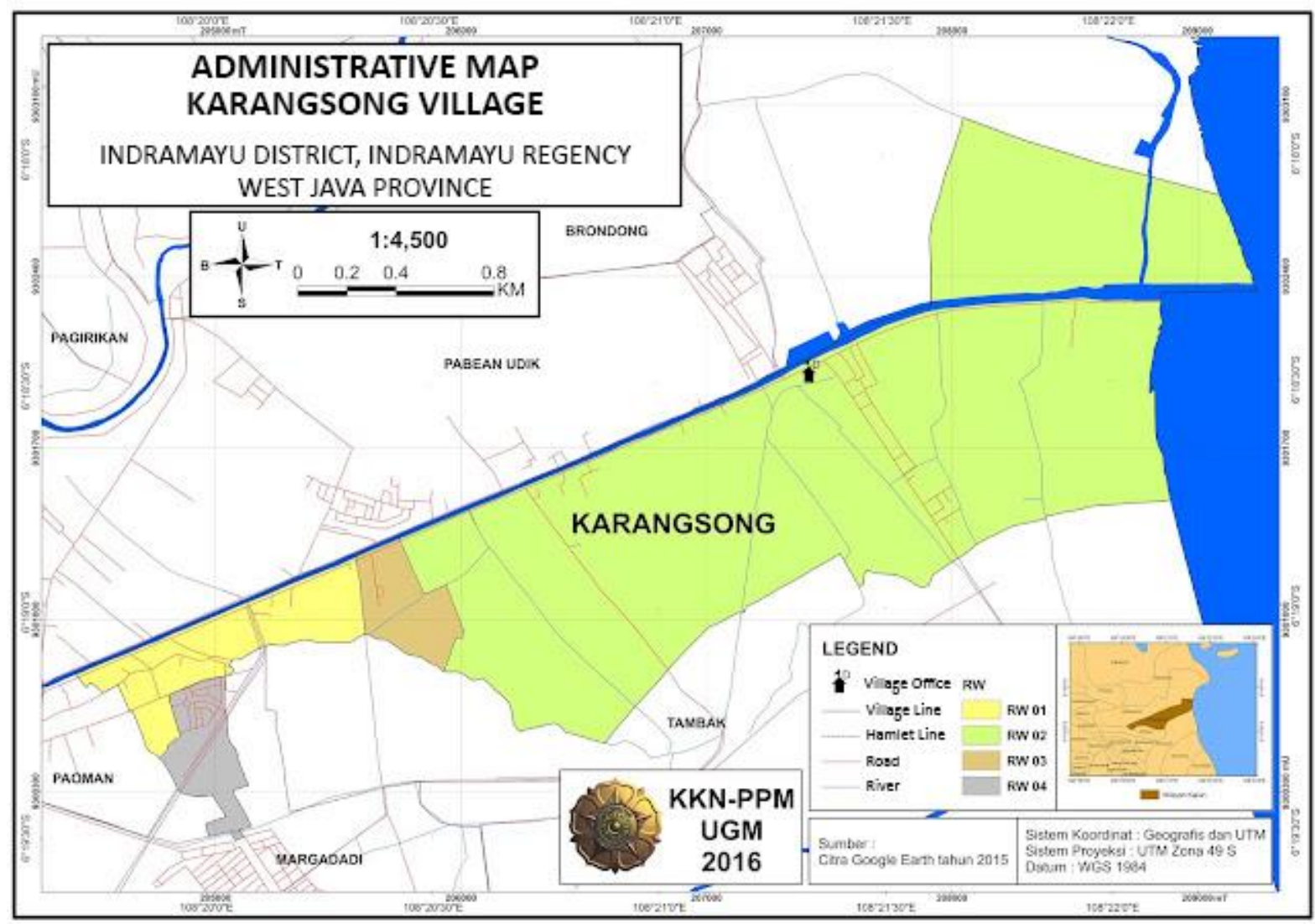

Figure 6. Administrative Map of Karangsong Village. Source: The Indonesian Ministry of Agrarian Affairs and Spatial Planning 2018. 
The aquaculture in Karangsong Village, Indramayu District, are shown by the fisheries culture and captured in the Fish Landing Base (TPI) of Karangsong as the main valuable strength for the locals. The Karangsong Village stated as the location of Minapolitan Fisheries of Indonesia by the Ministry of Marine Affairs and Fisheries (Tedi et al. 2020) to integrate and optimize the fisheries sector. The relation between natural resources and the fisheries activities from the Karangsong harbour to the Cimanuk River can create a physical interaction, economic, ecology, and social benefits, while shaping the implication of the aquaculture growth of Karangsong (Omat et al. 2008). Hence, the low Human Development Index in Indramayu in line with the Karangsong Village. Heriyanto (2016) mentioned that the Karangsong fisherman families still live with poverty issue in contrast with their abundance coastal resources. In fact, the maritime and fisheries data showed the gross income per fisherman in Indramayu Regency is low, only Rp. 46.741.860 per year (Heriyanto, 2016). While in 2010, the fishery production recorded 108.554,60 tons of Capture Fishery Products; Pond Yield 82.149,79 tons; Freshwater Pond Yield 51.852,35 tons; Public Water Products 5.544,10 tons; and Marine Cultivation Products 970,27 tons.

\section{Methodology}

\subsection{Field Survey: Karangsong Village and Indramayu}

All social and economic activities of the community in an area is reflected in the pattern of land use. This analysis is very necessary as an overview of the regional potential as well as to find out the distribution pattern socio-economic activities and the intensity of land use and various existing activities. The Study Area consists some agricultural areas managed by local communities. Most of this agricultural land is irrigated rice fields due to the quality of brackish water around region. In accordance with the characteristics of the coastal area, pond land and salt dominate the planning area. The Karangsong mangrove area is considered local tourist attraction ever since it was inaugurated since 2015 after the previous abrasion disaster. Karangsong mangrove ecotourism visitor shows positive trend since its inauguration. Apart from being a vehicle ecotourism, this mangrove rehabilitation area is also an educative attraction and natural laboratories. In addition, there are several tourist attractions beach developed independently by the community around and on the development of local government. Most of these beaches have limited accessibilities and do not have adequate facilities.

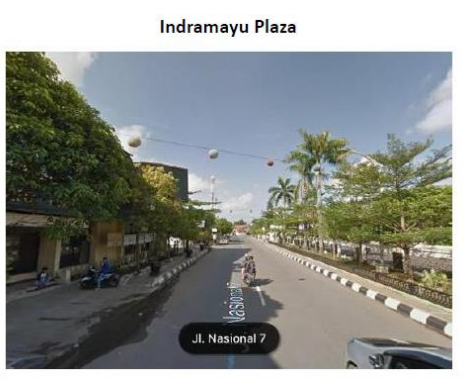

Activity Center

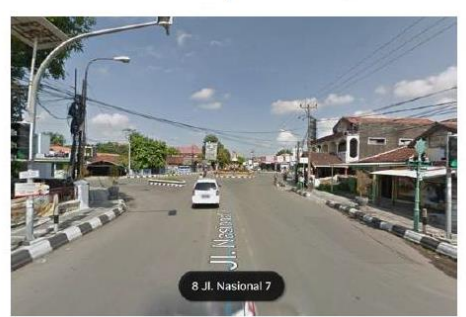

Government Area

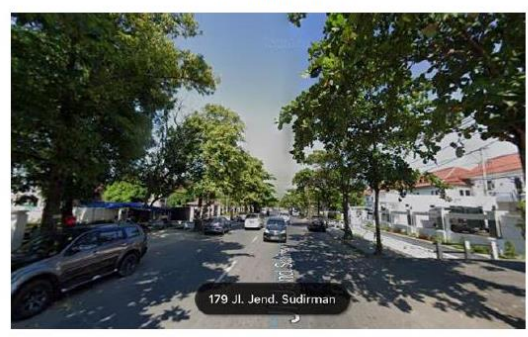

Karangsong Coast

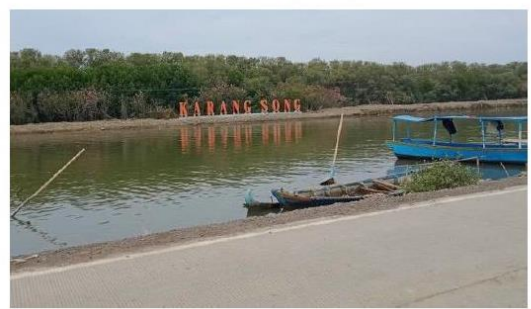

Refinery Unit Pertamina

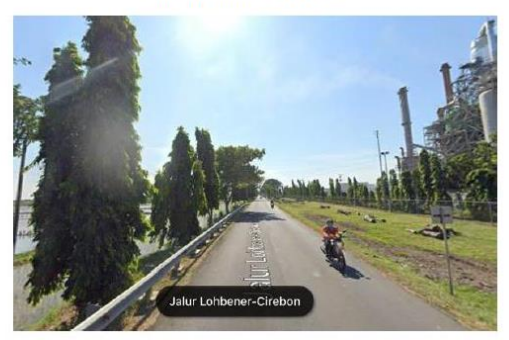

Indramayu Islamic Center

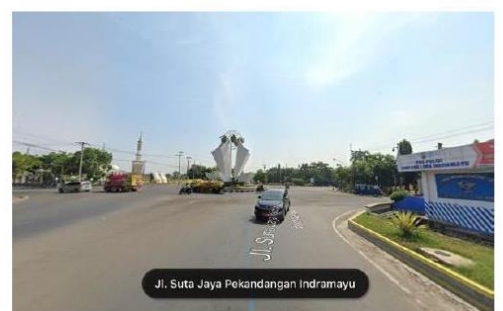

Figure 7. Existing Streetscape. Source: Google Maps 2021. 

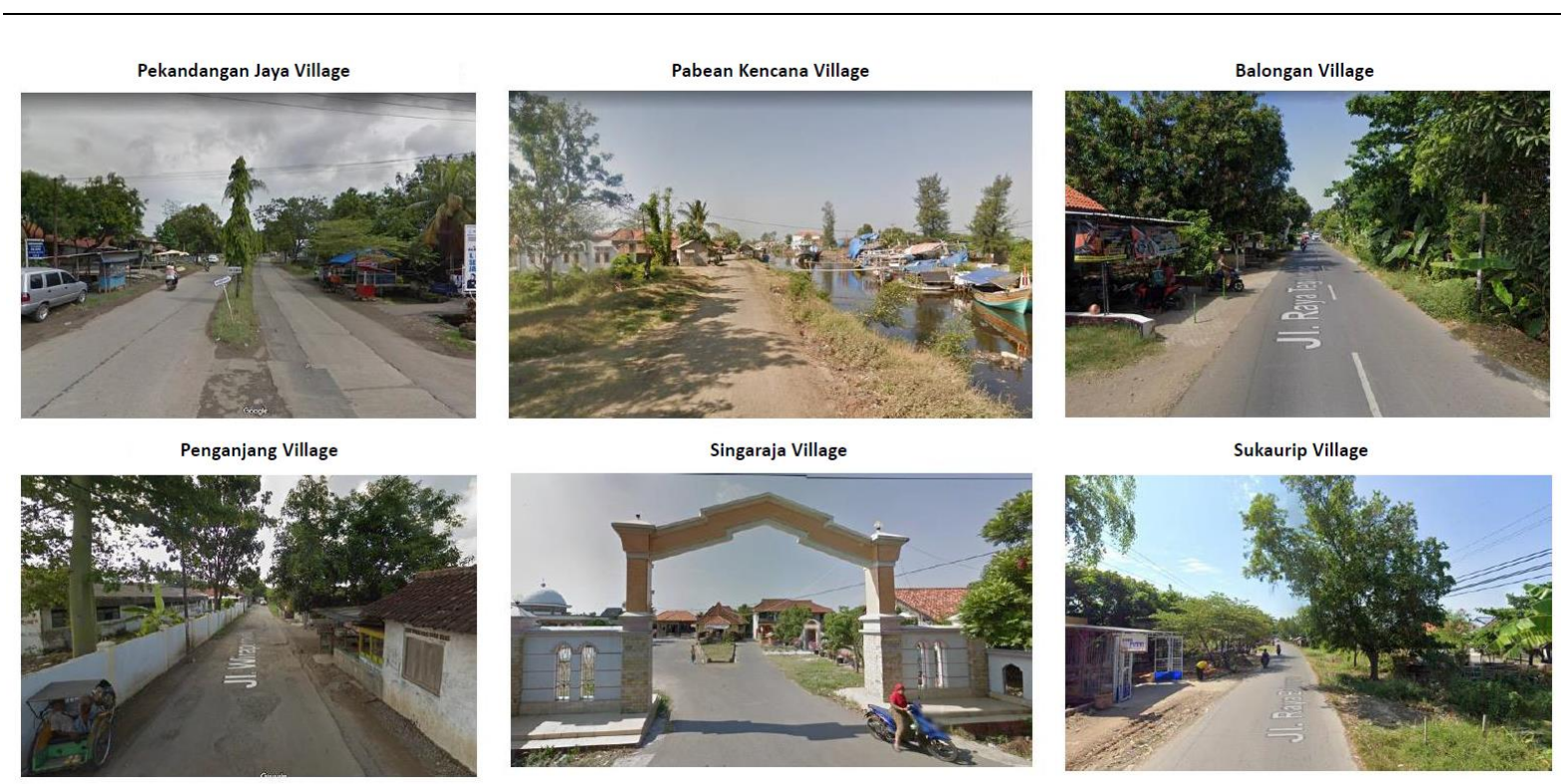

Figure 8. Surrounding Villages. Source: Google Maps 2021.

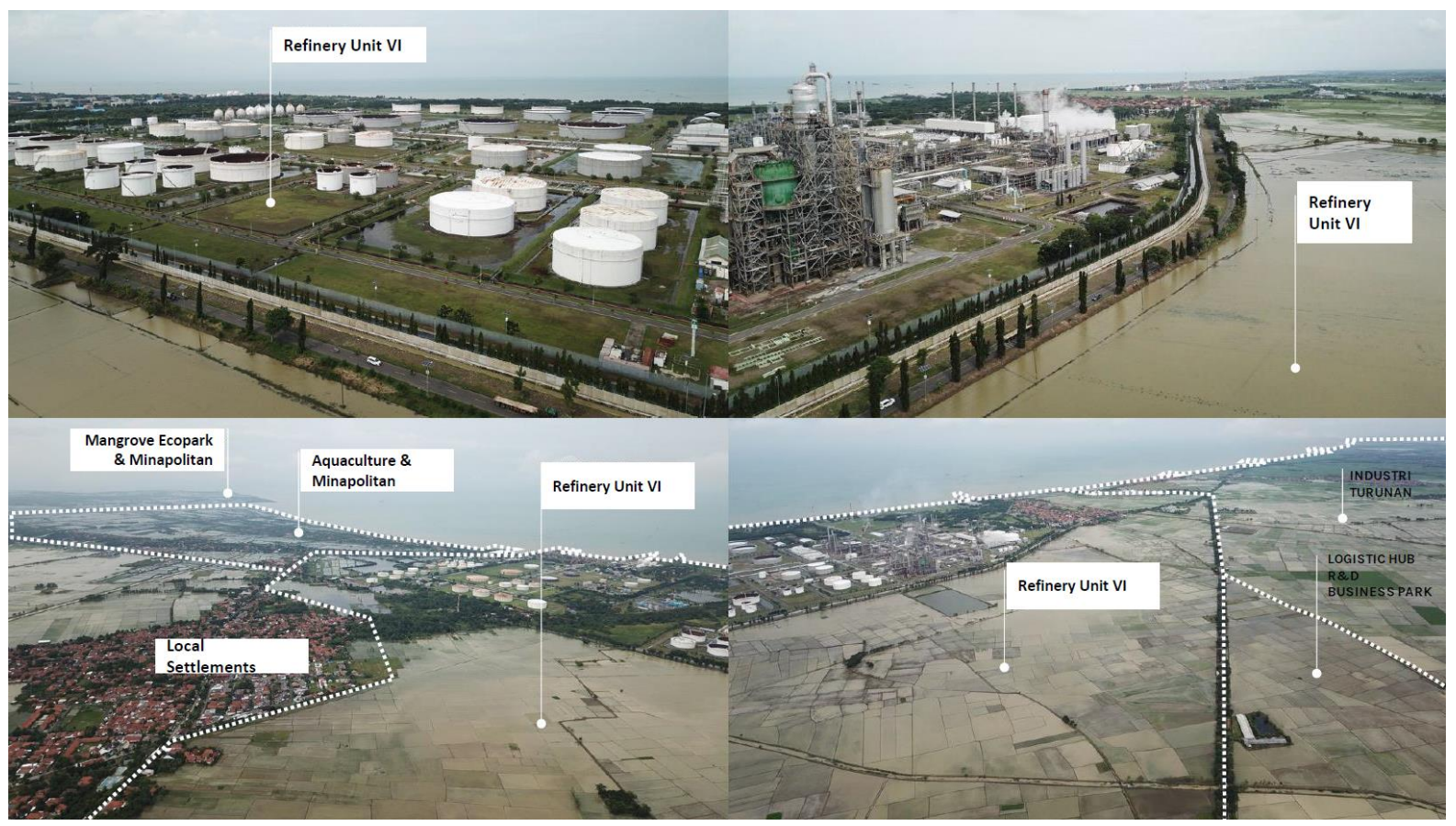

Figure 9. Surrounding Conditions. Source: Team Survey, 2021. 


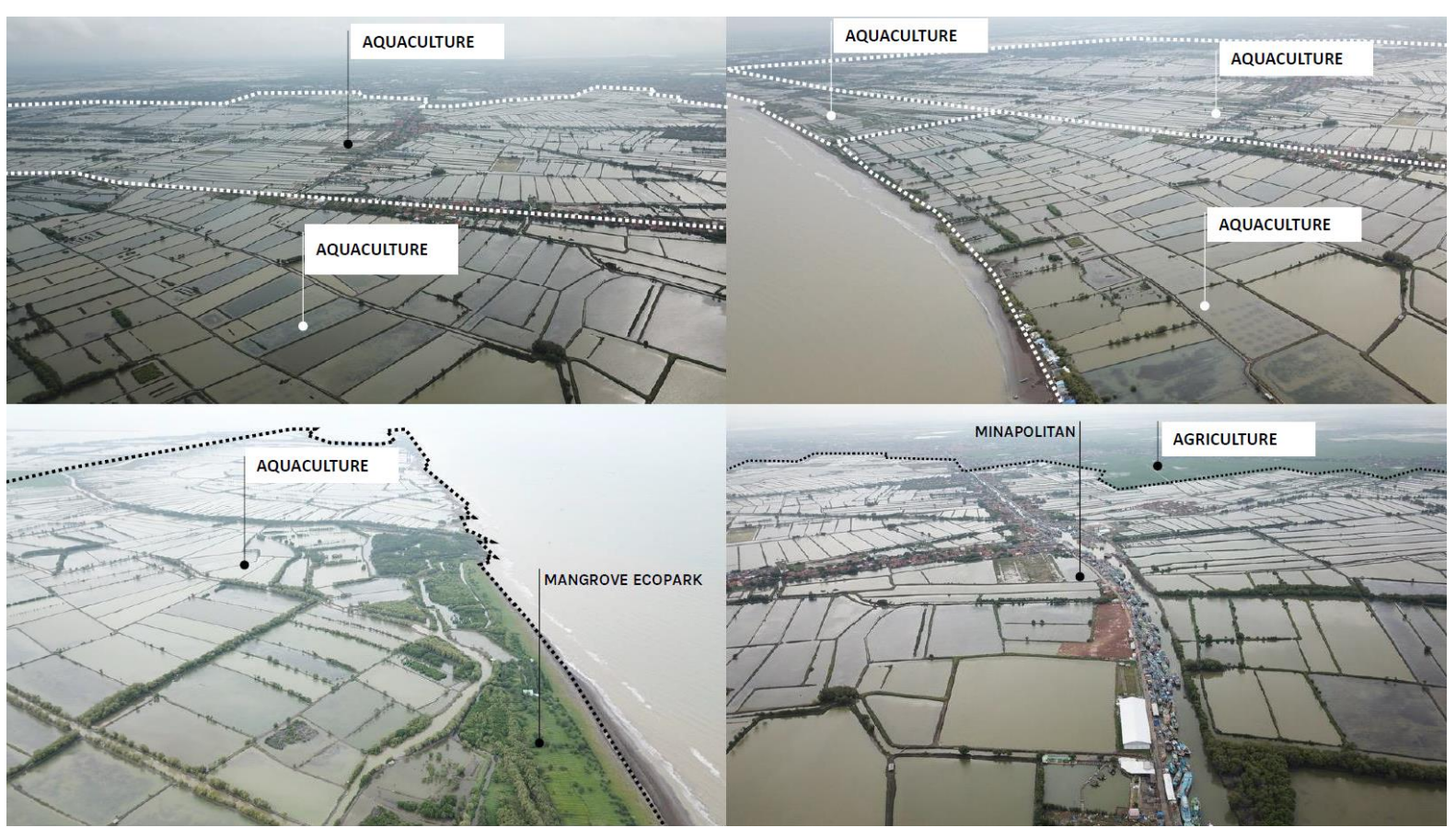

Figure 10. Surrounding Conditions. Source: Team Survey, 2021.

\subsection{Data Collection}

Data collected in the form of both primary data taken from field survey, resulting in observations and secondary data taken from various sources and media, generally from the internet. These data will be the basis in identifying the potential and problems existing in the study area. Furthermore, the potentials and challenges are separated into internal potentials and problems (internal potential $=$ Strength, internal problems $=$ Weakness) as well as external potentials and problems (external potential $=$ Opportunities, external problems $=$ Threats).

\subsection{Exploratory and Qualitative Approach: Urban Aquaculture Facets Assessment through}

\section{SWOT Analysis}

The potentials and challenges are the starting points for Bürgow's two strategic recommendations entitled "Design-build strategies: Aquatecture" and "Participatory process strategies: Aquapuncture". The two strategies are at different levels: Aquatecture addresses architectural and urban design, while Aquapuncture highlights (temporary, systematic) spatial experimentation and approaches to participation and environmental education (built). 


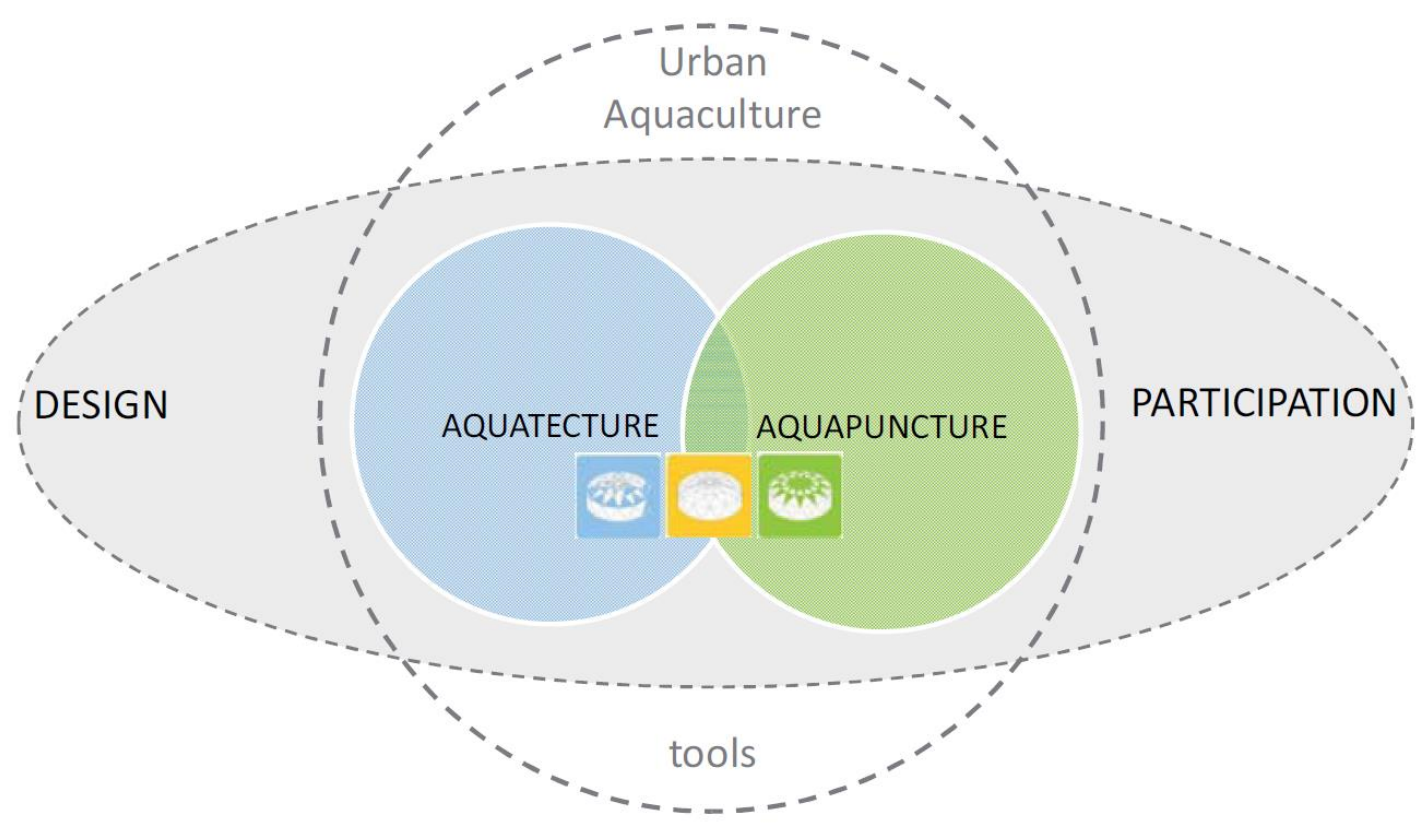

Figure 11. Aquatecture and aquapuncture as creative tools of water-sensitive urban design and participation to catalyze urban aquaculture. Source: Burgow, 2013.

On that basis, SWOT analysis is used as the chosen methodology since both use inputs in the form of potentials and problems/challenges, and produce strategies as the outputs. To enrich the SWOT process, we use 3 spheres of urban aquaculture burgow, namely water living culture (shipping-building), waterfarming culture (fishing-food), and water-wellbeing culture (drinking-swimming), in identifying Strength, Weakness, Opportunities, and Threats. In addition, the strategies resulting from the SWOT process will be divided into two burgow strategies, namely aquatecture and aquapuncture.

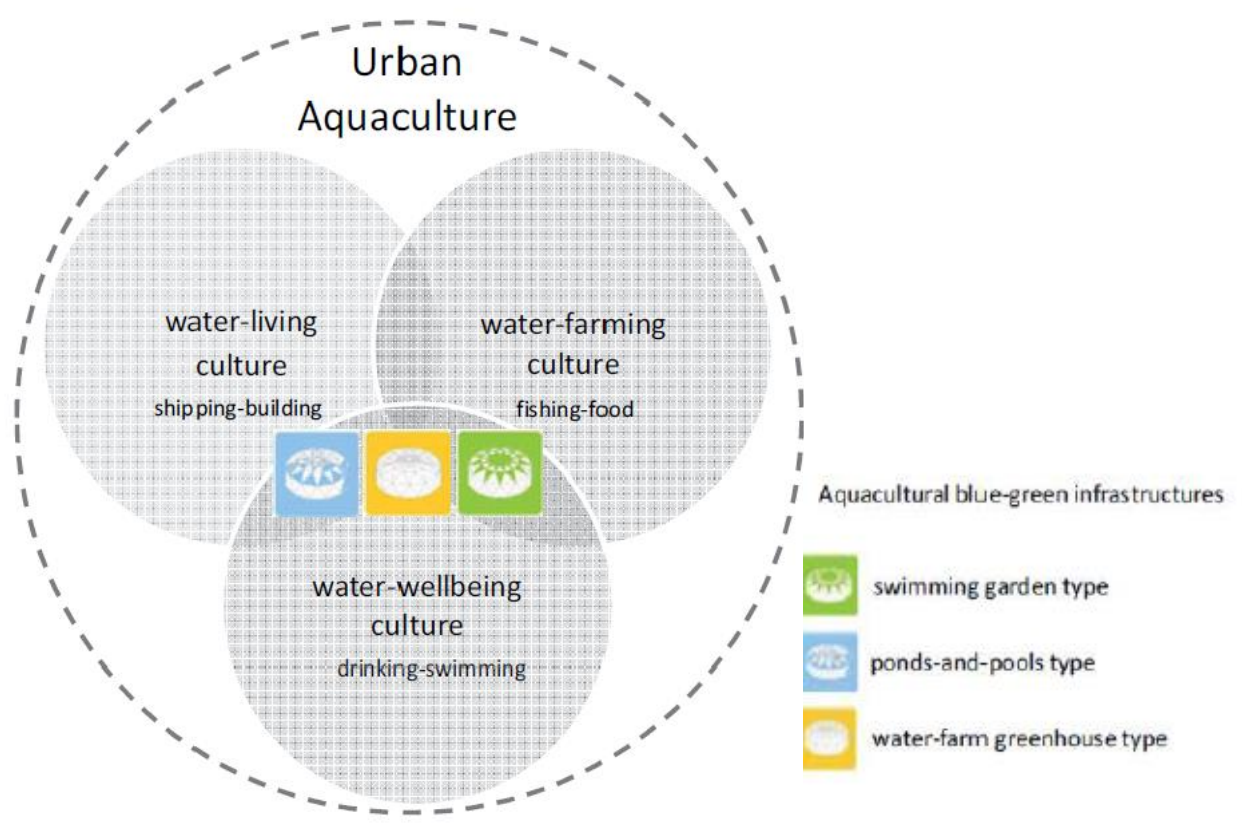

Figure 12. Urban Aquaculture Facets. Source: Burgow, 2013. 


\section{Findings}

\subsection{Urban Aquaculture Facets Assessment}

The facets assessment of urban aquaculture based on the evaluation of the strength, weakness, opportunity, and thread of the area. Karangsong faces many external threads to be identified, the common future thread also included climate change issues, sea-level rise, and abrasion. It may deepen the notable potentials and weakness of the facets for common understanding the use of water, management, planning, and design to be fostered. Furthermore, the SWOT analysis identification will be assessed in relation with urban aquaculture strategy and followed by three characteristics facets: waterfarming culture, water-living culture, and water-wellbeing culture.

Burgow (2014) entitles two different levels of urban aquaculture strategy. The first, Aquatecture as the Design and Build Strategy, which addresses the perspective of design and build by stressing the management orientation of design-resource. Aquatecture also highlights the urban design and architecture, in Karangsong context it appears as the main infrastructures, TPI, harbour, fisheries facilities services, the accessibility network, and the natural structures. Secondly, Aquapuncture appoints the communication and collaborative intervention aspects on participatory process level. It requires the assessment of work and communication across multi-stakeholders and multidisciplinary practice with diverse stakeholders.

\subsection{Water Living-Culture Assessment}

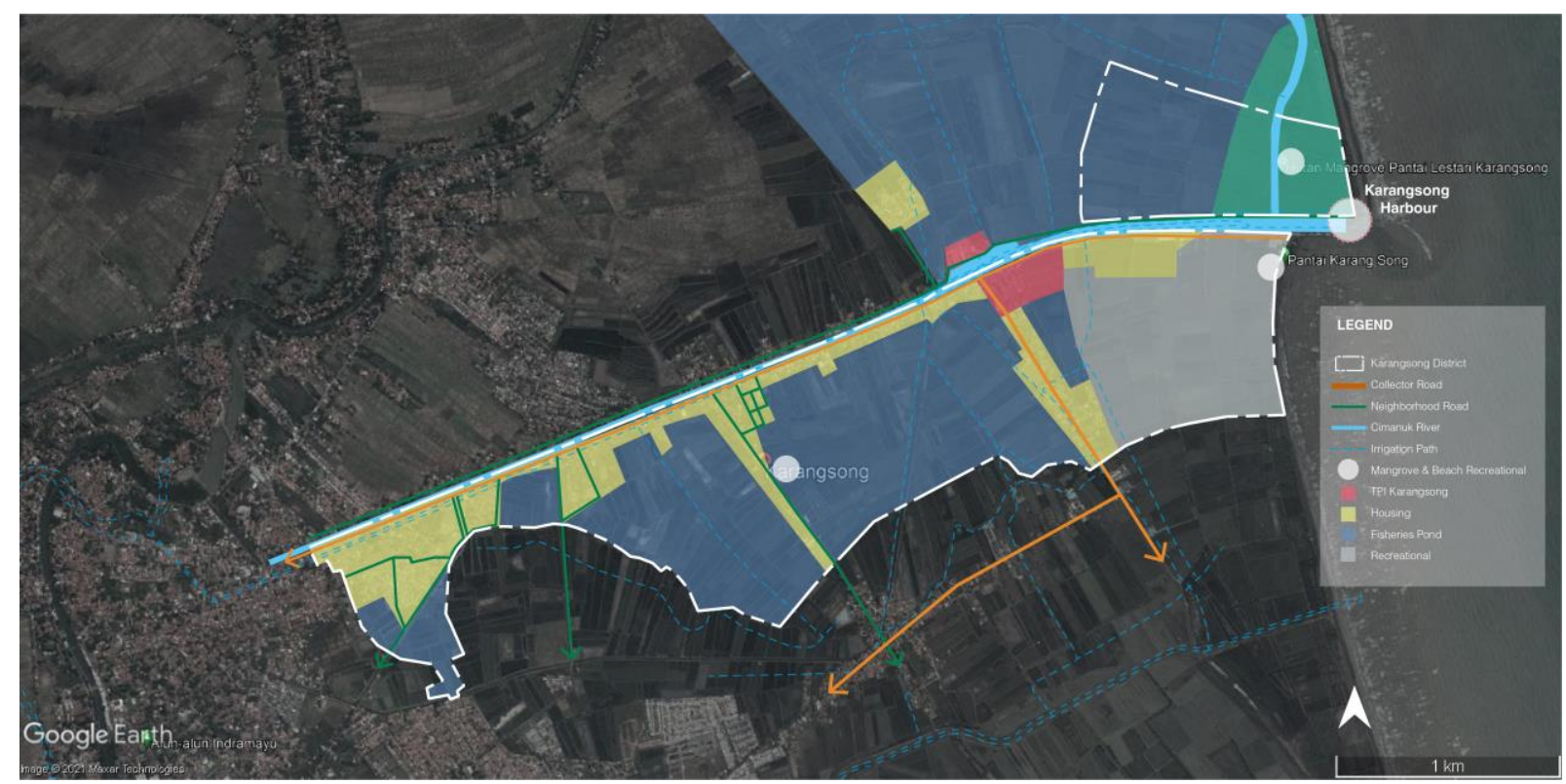

Figure 13. Water-living supporting infrastructures. Source: Team Analysis.

Karangsong had aquaculture typologies, such as ponds fisheries, riverfront settlement, mangrove conservation, and specific integration between blue-green infrastructures. The Water Living-Culture exposed the aquaculture infrastructure of Karangsong character in its place-based context. It refers to water-based transportation and building practices, such as shipping, harbour infrastructure, and living at the water. The fisherman and pond-fisheries cultivation highlight the availability and readiness of the physical infrastructures, while creating the water-living culture among the inhabitants. The forms and practices of water-living, such as dwelling, trading or living by the water-shore, mangrove, and riverfronts in Karangsong is explored through: 
Strength: 1) Karangsong Harbour existed with historical value, strategic position, and functioned as the primary transportation for fisheries-captured, shipping, and distribution from the sea to the river of the village; 2) TPI (Fish Landing Base) is well-organized and functioned as the fisheries market facilities. 3) Had wide land coverage for pond-fisheries with irrigation, and mangrove conservation.

Weakness: 1) The minapolitan program is facing the low human development index; 2) The lack of infrastructure access from Karangsong to the Indramayu region for supporting the fisheries market; 3 ) The spatial planning system of Karangsong district is weak, showed by the lack of facilities and the sprawled river settlement around the TPI to support the economic income. 4) The integration of bluegreen infrastructure between the shipping industry, fisheries captured, pond-fisheries, and mangrove are not optimized.

Opportunity: 1) Karangsong projected as part of the future minapolitan program of Indramayu regency by Indonesia's Ministry of Marine Affairs and Fisheries; 2) The product market of captured fisheries, pondfisheries, and mangrove conservation can improve the human development index by their attractiveness and investment mechanism; 3) The land coverage area and the production quantity for export and import activities can compete with market as well to fulfill the demand consumption in wider range; 4) Karangsong district infrastructure can be improved by the procurement as the center for developing the natural and human resources, through the circular system of fish cultivation center, feed processing, fisheries product processing area, shipping construction center, cold storage factories, hygiene fish markets, and mangrove habitat conservation areas.

Threat: 1) The decline of the environment quality and fish resource carrying capacity; 2) The economic resilience is not supported by the spatial planning system and the local management; 3 ) The degradation of fishermen living condition infrastructure; 4) The coastal area of Indramayu is already densely caught, the fishing ground distance is far away to access.

\subsection{Water Farming-Culture Assessment}

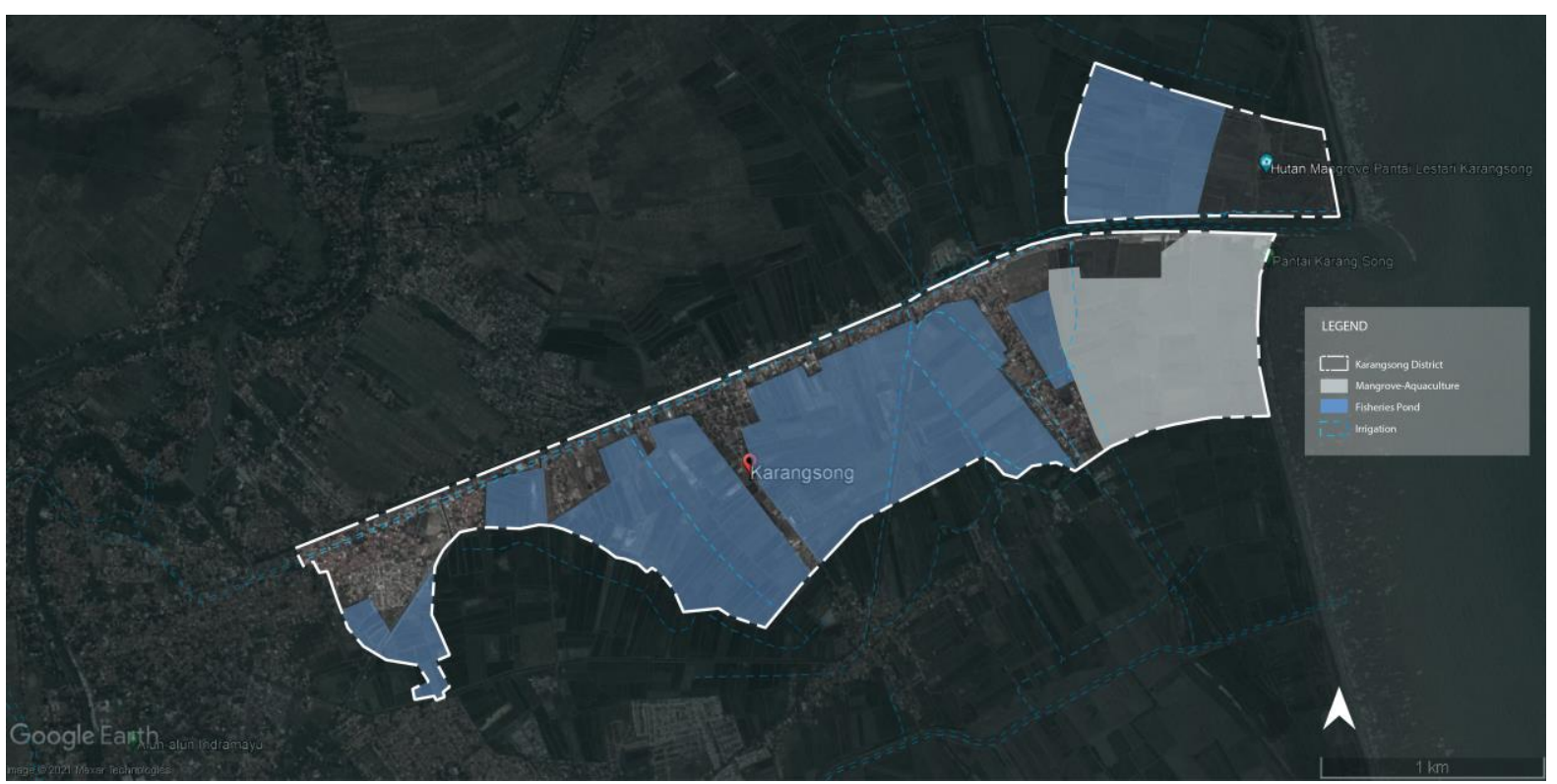

Figure 14. Water-Farming watershed. Source: Team Analysis.

Water Farming-Culture explores aquacultural infrastructure involving water-based farming activities provided by -but not limited to- fish pool and water-balancing landscape. Reflecting back to existing infrastructures available in Karangsong Villages, fish pools are available in a form of conservative, traditional aquaculture ponds, where water-balancing landscape comes in a form of coastal aquaculture ponds supported by mangroves belt. These fish pools. 
Strength: 1) Fishing activities have become the root culture of the citizens, meaning there's no longer comprehensive urge to raise the awareness of the aquaculture significances, 2) Inland fisheries capture of Karangsong is considered highly competitive, meaning a broader market values the products sold in Karangsong, 3) Effortless availability of large fishing ponds as natural resources have also become another urgency to optimally cultivate the existing resources.

Weakness: 1) Lack in supporting infrastructures; the unavailability of proper incubators for the seeds has prevented the possibility of optimizing the cultivation of these pools, 2) Distribution system that is not fully beneficial for the local fishermen, 3) Lack in possibilities improvement in farming wider range of fish

Opportunity: 1) Karangsong as Minapolitan, 2) Strategic location of Karangsong, 3) Market for the fish captures that covers wide scope, 3) Open Investment Program.

Threat: 1) Poverty, limiting chance of improvements in the capture technology, 2) Existing competing market outside Karangsong Village.

\subsection{Water Well-being Assessment}

The third facet of the urban aquaculture sphere focuses on the water-wellbeing culture assessment. Water-wellbeing culture highlights the water-centric human wellbeing, the relation between human and water activities, drinking, swimming, including psychological, spiritual, and physical wellness factors. It concerns of daily use and handling of water as element of life and cultural resource. The identification of the past and present condition on how Indramayu and Karangsong at micro scale use the water can be assessed through the relation between the inhabitants and the Cimanuk River, as well as the activities in the Karangsong coast.

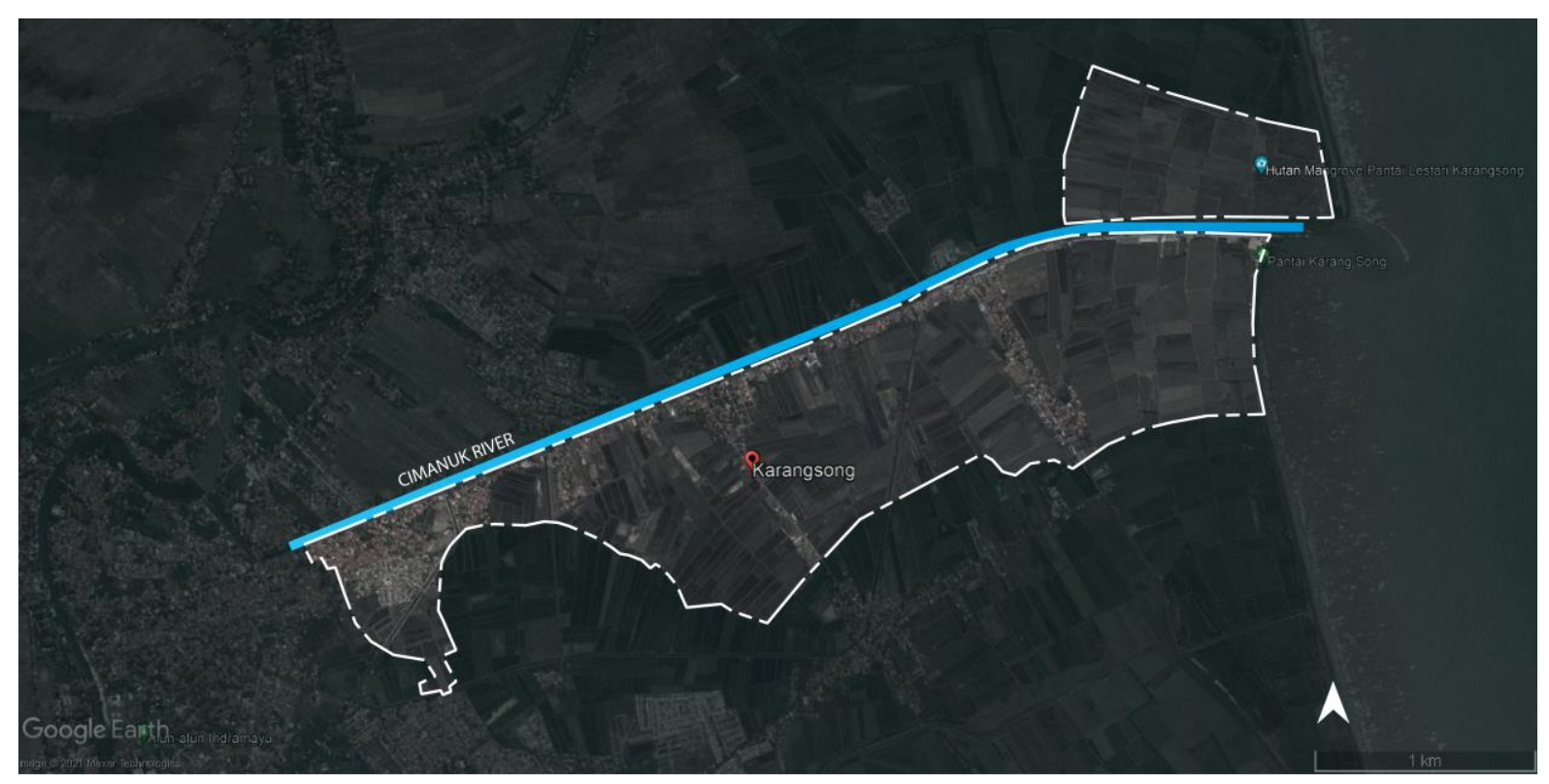

Figure 15. Cimanuk River as the Main Waterbody in Karangsong. Source: Team Analysis.

Strength: 1) The identity of the maritime spirit as part of historical values and cultural symbol; 2) Cimanuk River is the only water resource for daily use, such as drinking and washing; 3) The existing tourism area can support the recreational wellbeing aspect. 
Weakness: 1) In dry season the obstacle of water unavailability and decreasing volume of Cimanuk River and irrigation canals; 2) Water shortage area in Karangsong and Indramayu Regency; 3) The continuous degradation of water quality and quantity is inadequate with the water usage demand.

Opportunity: 1) Use the waste-water management to optimize the water resource daily use from the Cimanuk River, brackish water, and the Karangsong Sea Water; 2) Appliance the technology of distillation in response of the high temperature in dry season and highly sun exposure of Indramayu Regency; 3). The CSR mechanism of RU VI Pertamina Balongan in Indramayu Regency can be the investment solving for the unavailability of water wellness infrastructure.

Threat: 1) The local habits of ground-water consumption can threat the quality of environment; 2) Climate change issues, sea-level rise, and abrasion can be the thread for the riverfront activities.

\subsection{Prospective Resiliency Plans in Aquatecture and Aquapuncture}

Overall, the potentials and challenges mentioned based on the three spheres above revolve around the unavailability and inefficiency of several existing infrastructure used in daily life. Most of the potentials and issues are rooted from multi-disciplinary aspects ranging from spatial planning, environment, infrastructure, transportation, and socio-economical aspect. The internal factors are classified as:

\section{Strength}

1. Balongan as Provincial Strategic Area;

2. High Contribution from local industries in Indramayu to West Java;

3. Plenty of natural resources especially inland and sea fisheries.

\section{Weakness}

1. Low performing human resources;

2. Inefficiency of daily infrastructure standards.

Whereas external factors are classified as:

\section{Opportunities}

1. Indramayu as Minapolitan Area of Western Java;

2. Increase in agriculture and fisheries production;

3. Local communities as local identity;

4. Development in tourism and nature preservation.

\section{Threats}

1. Weakness in disaster mitigation;

2. Optimization of Land Use compared to existing conditions. 
All internal and external factors are then analysed, resulting matrix of strategic resiliency plans such as:

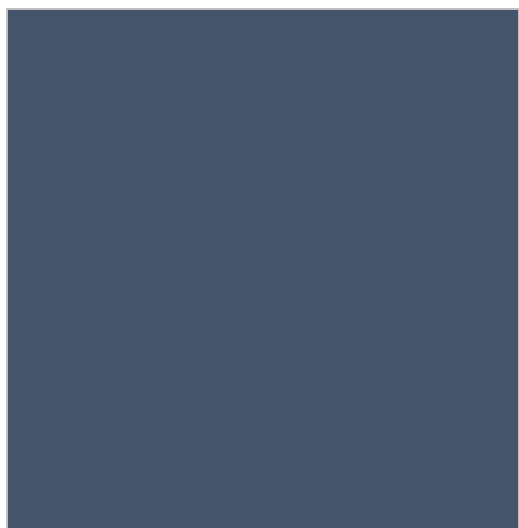

\section{Opportunities}

1. Indramayu as Minapolitan Area of Western Java

2. Increase in agriculture and fisheries production

3. Local communities as local identity

4. Development in tourism and nature preservation

\section{Threats}

1. Weakness in disaster mitigation

2. Optimization of Land Use compared to existing conditions

\section{Strengths}

1. Balongan as Provincial Strategic Area

2. High contribution from local industries in West Java

3. Plenty of natural resources especially inland and sea fisheries

Strengths - Opportunities

1. Improvement in accessibility and quality of transportation to optimize economic activities in the area $(\mathrm{S} 1,2-01)$

2. Improvement in daily infrastructures supporting economic activities (S2,3$02,4)$

3. Improvement in Integrated economic activities including improvement in human resources in local communities $(\mathrm{S} 2,3-03,4)$

\section{Strengths - Threats}

1. Optimization in land use prioritizing industrial goods distribution and accessibility of the strategic area

2. Integration of daily infrastructures with disaster mitigation plan

\section{Weaknesses}

1. Low performing human resources

2. Inefficiency of daily infrastructure standards

Weakness - Opportunities

1. Improvement in the usage and control of Land Use in order to support economic activities and local prosperities (W1 - 02,3)

2. Strategies in supporting nature preservation in order to sustain land carrying capacity (W2 04)

\section{Weakness - Threats}

1. Clean water provision and public facilities planning

2. Improvement in designing green public spaces along natural borders (river, coastal boundary line) to anticipate sedimentation risk

3. Disaster mitigation strategic planning

Table 1. Matrix of Strategic Resiliency Plans. Source: Team Analysis. 
Based on the SWOT Analysis mentioned above, the strategic resiliency plans can further be divided into two tangibility classification: Aquatecture, which might be implemented through design process such as Masterplan and Aquapuncture, which might be implemented through planning process such as Building and Environmental Planning. The resiliency plans assorted through aquatecture and aquapuncture are:

\section{Aquatecture}

1. Improvement in accessibility and quality of transportation to optimize economic activities in the area such as local road and accessibility to Karangsong Village;

2. Improvement in daily infrastructures supporting economic activities such as designing proper irrigation, ports and fisherman wharf;

3. Clean water provision and public facilities planning such as desalination port;

4. Improvement in designing green public spaces along natural borders (river, coastal boundary line) to anticipate sedimentation risk such as Associated Mangrove Aquaculture application, bioswale implementations;

5. Strategies in supporting nature preservation in order to sustain land carrying capacity such as revitalization of mangrove preservation area.
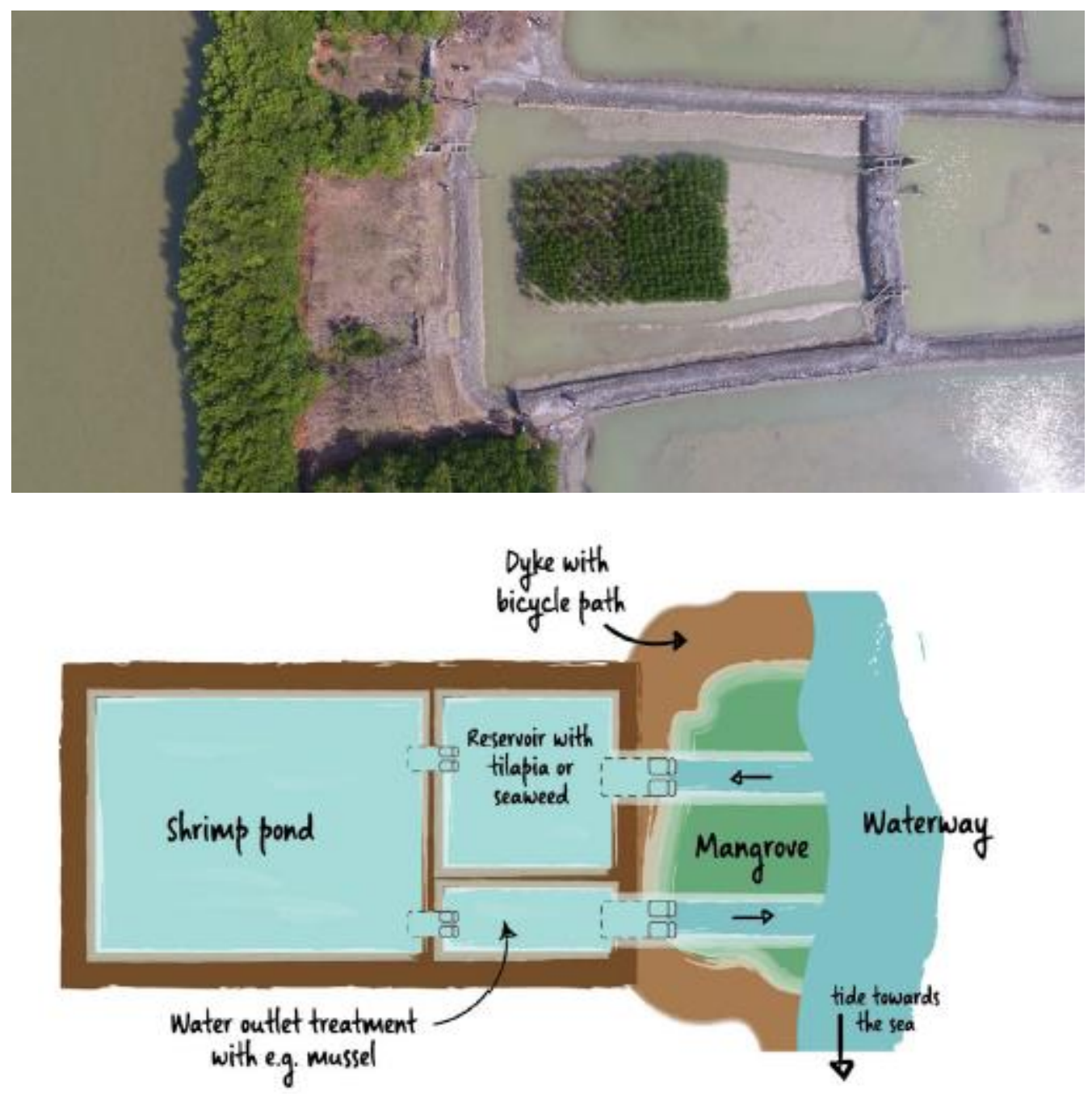

Figure 16. Aquatecture: Application of AMA Farm. Source: Wetland International. 


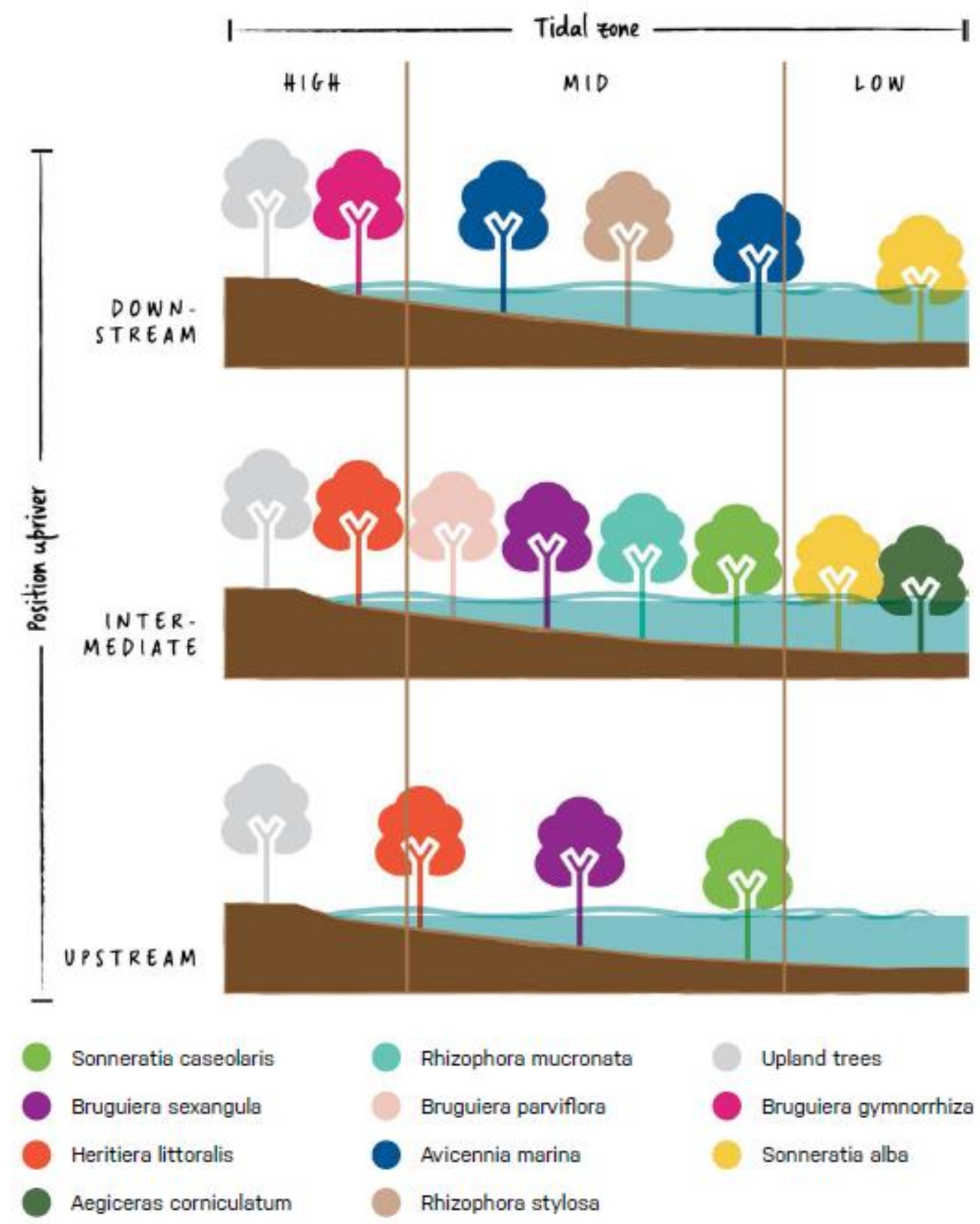

Figure 17. Aquatecture: Abrasion Risk Anticipation through Landscape. Source: Wetland International. 


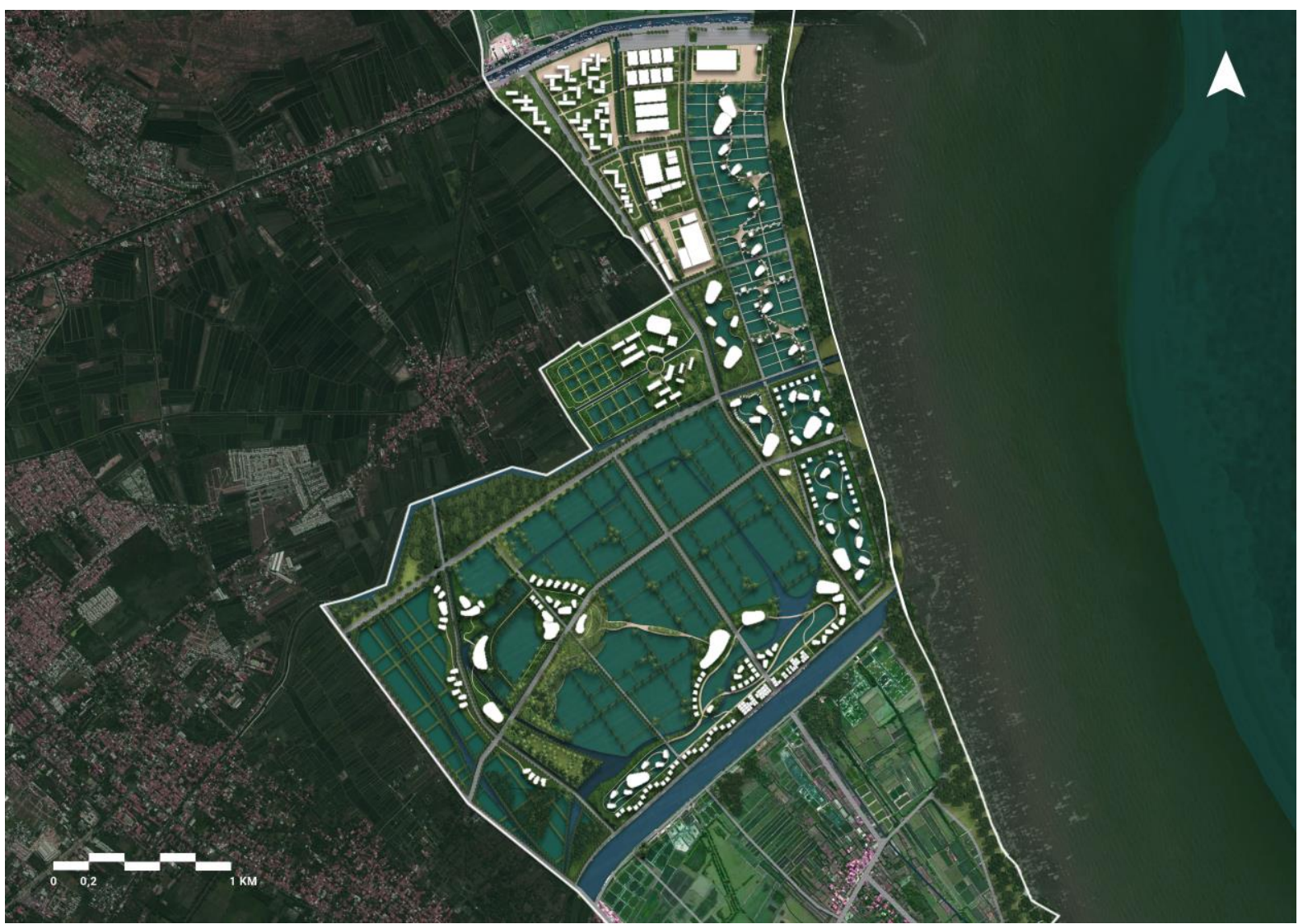

Figure 18. Aquatecture: Karangsong Aquaculture and Minapolitan Masterplan. Source: Team Analysis.

FISHERMAN WHARF, SAN FRANSISCO
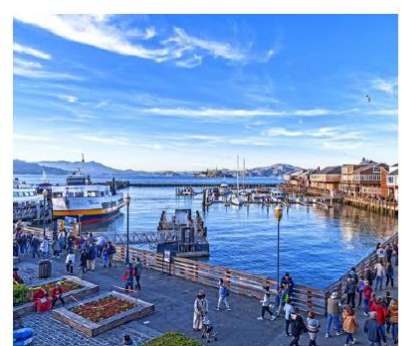

TOYOSU FISH MARKET, TOKYO

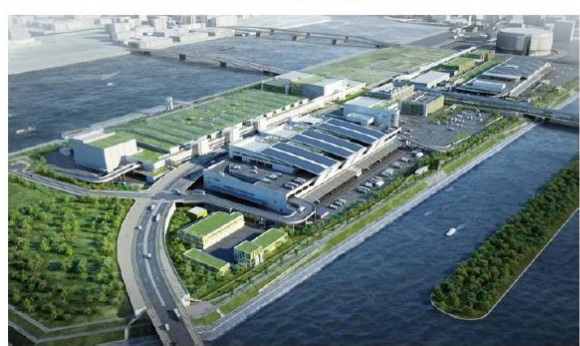

TAMAN MANGROVE PURI MAEROKOCO

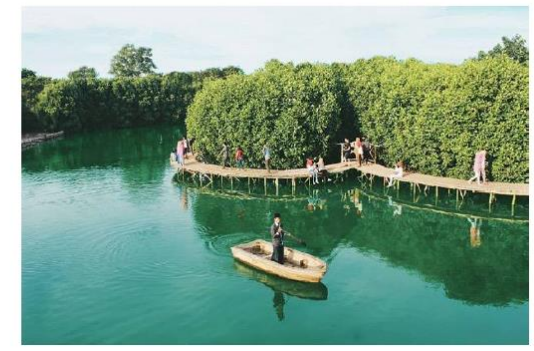

Figure 19. Aquatecture: Minapolitan Precedents. Source: Archdaily.

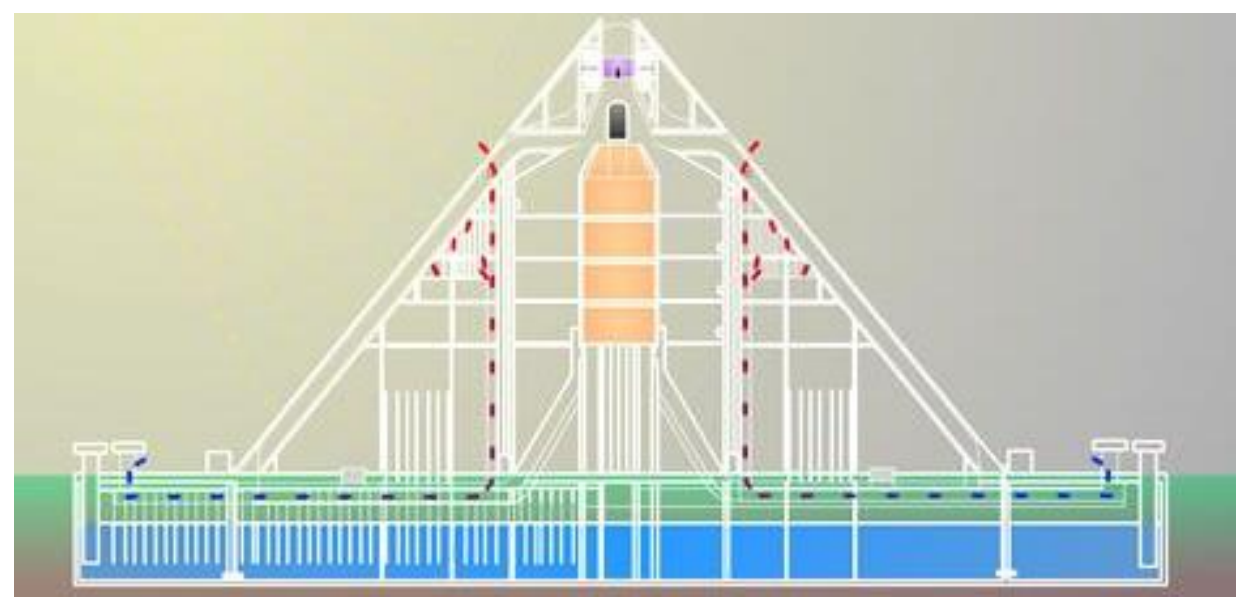

Figure 20. Aquatecture: Desalination Installation. Source: Treehugger. 


\section{Aquapuncture}

1. Improvement in Integrated economic activities including improvement in human resources in local communities;

2. Optimization in land use prioritizing industrial goods distribution and accessibility of the strategic area;

3. Integration of daily infrastructures with disaster mitigation plan;

4. Improvement in the usage and control of Land Use in order to support economic activities and local prosperities;

5. Strategic Disaster mitigation planning.

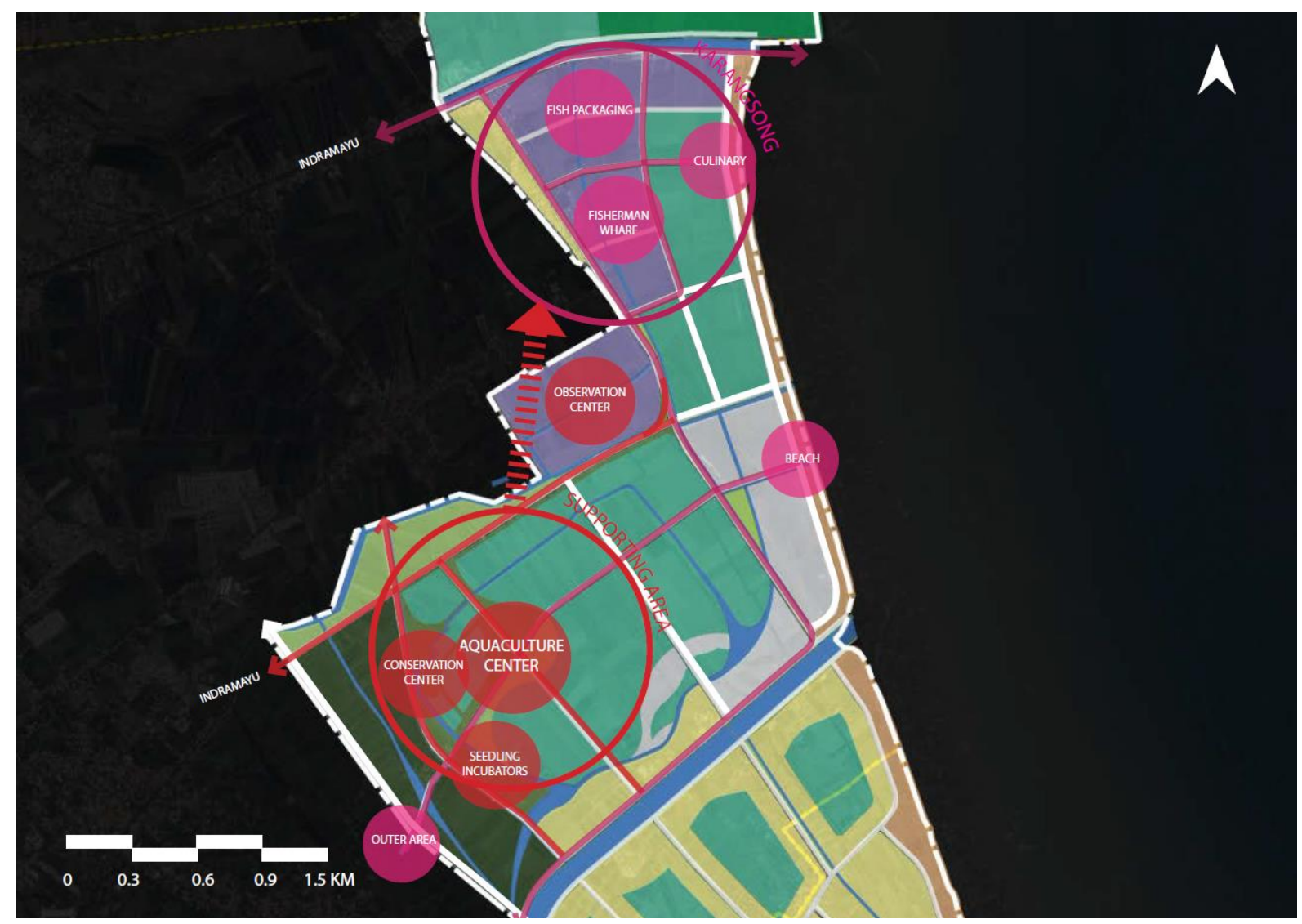

Figure 21. Aquapuncture: Strategic Distribution Framework for Inland Fisheries. Source: Team Analysis.

\section{Conclusion}

The future of Minapolitan Area must possess the strength in cultivating the abundant both natural and man-made resources in the most optimum and sustainable way possible. In order to prepare Indramayu to be a prime Minapolitan Area in Western Java, Karangsong Village as one of the most productive port in the coastal area of Indramayu has a great potential to lead the improvements in daily infrastructures supporting the existing natural resources- aquacultures. Being located in the coastal Indramayu has made Karangsong Village exposed to several disaster risk such as abrasion and erosion. In the other hand, Karangsong Village should also be able to provide prosperities to its citizens. 
In this case, resiliency in mitigation scenario and economical condition should be prepared further. Assessed through urban aquaculture facets by Burgow and analyzed using SWOT methods, Karangsong Village provides proper resources and strategic area as a good starting point for any potentials in environmental and economic resiliencies. Yet several progressive improvements are to be made especially in the developments of daily infrastructures ranging from optimization of irrigation, revitalization of the Karangsong port, and provision of desalination centers in several area. The vision of Minapolitan area can be realized through proper cultivation and management of aquaculture and its industries. In order to breakdown the internal and external factors of the process, the SWOT Analysis is broken down into two implementative steps such as Aquapuncture, working as planning regulation, and Aquatecture, infrastructure provisions through designs.

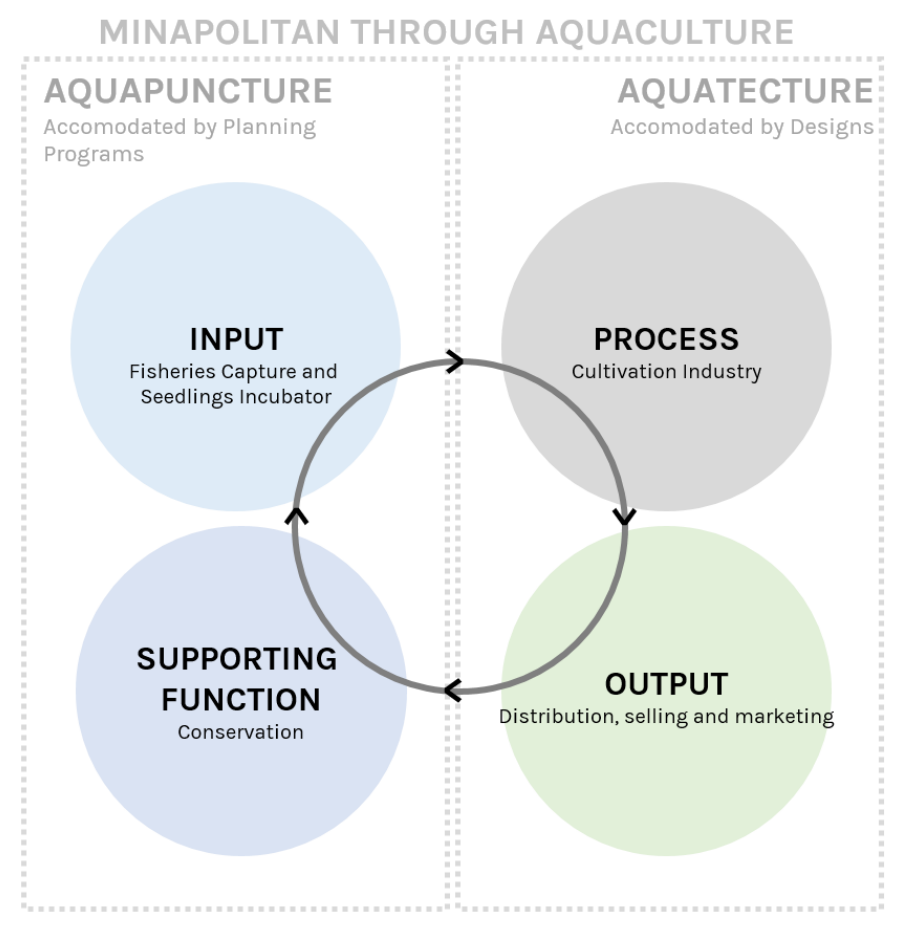

Figure 22. Aquapuncture \& Aquatecture: Complementary Set of Resiliency Plans. Source: Team Analysis.

Through the classification of aquapuncture and aquatecture, further strategical approaches can be classified even further in order to fit the standardized requirements of statutory plannings. Overall, in order to prepare Karangsong's readiness to hold a role of future Minapolitan Area of Western Java, the mitigation and economic resiliency can be achieved through a set of strategic coastal developments such as Infrastructure Resilience in order to provice strong, resilient system of the existing industries, Spatial Synergy to integrate existing needs of economic activities, Urban Accessibility for a more accessible area, Socioeconomic Enrichment for prosperity provisions, and Environmental Sustainability as an anticipative step for disaster mitigation plan in the future. 


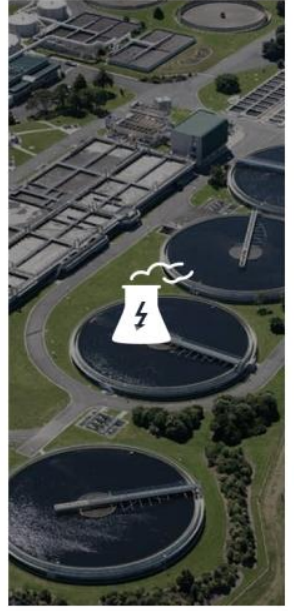

INFRASTRUCTURE RESILIENCE

Building a modern and productive
symbiosis within Karangsong symbiosis within Karangsong Village and its surrounding
through strengthening the carrying through strengthening the carrying
capacity of resilient infrastructure
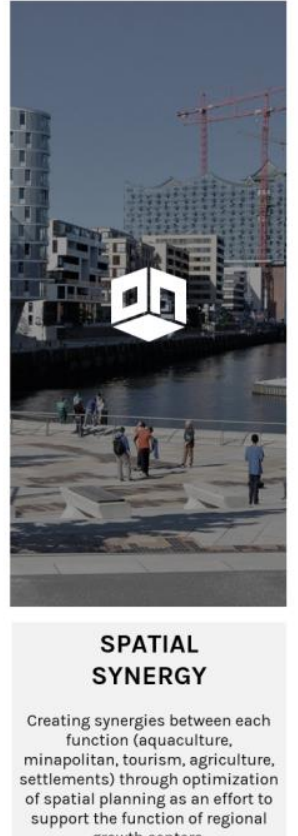
growth centers.

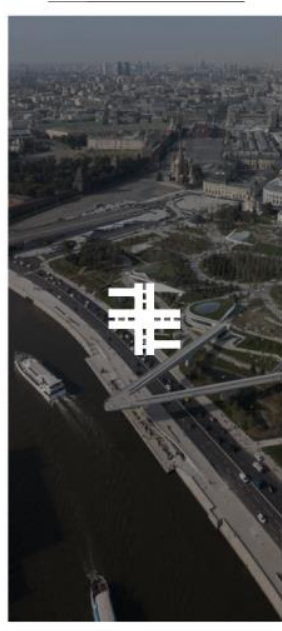

URBAN ACCESSIBILITY

Realizing a new, progressive and accessible area in order to achieve regional integration supported by transportation nework structures.

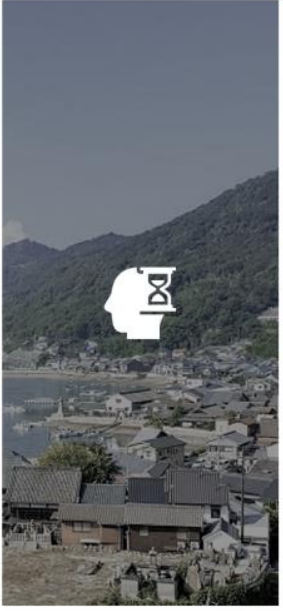

SOCIOECONOMIC ENRICHMENT

Supporting the development of new urban areas that are inclusive based on the diversity and integration of adaptive and an effort to respect regien locality.

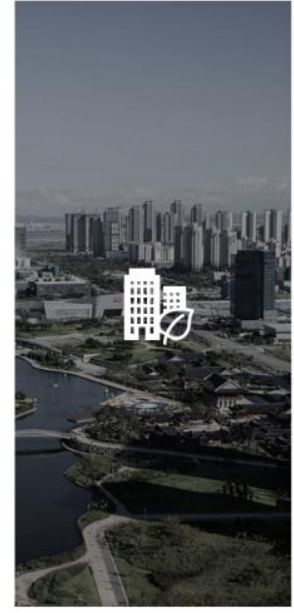

ENVIRONMENTAL SUSTAINABILITY

Realizing a resilient coastal area by preparing the disaster mitigation scenarios, balance between the preservation of the natural activities in order to achieve a green, smart and sustainable are

Figure 23. Coastal Development Resiliency Plans. Source: Team Analysis.

Putting the limitation of the scope of this paper, further study is required in order to create an integrated framework of implementative scenarios that are not only providing for the area, but also optimizing the improvements possible in Karangsong Village. Suggestive framework of the detailed implementation plan recommends defining tools and programs in the realization of the resiliency in a participatory planning. Participatory planning maximizes the possibility of implementing the practical and technical steps for it opens a broader perspective especially from those participators that are affiliated and impacted from and within this process. Participatory planning also helps create a more inclusive and measured system for decision making, especially involving related stakeholders and local communities so the future of coastal area can emerge in the most resilient way possible- both tangibly and intangibly.

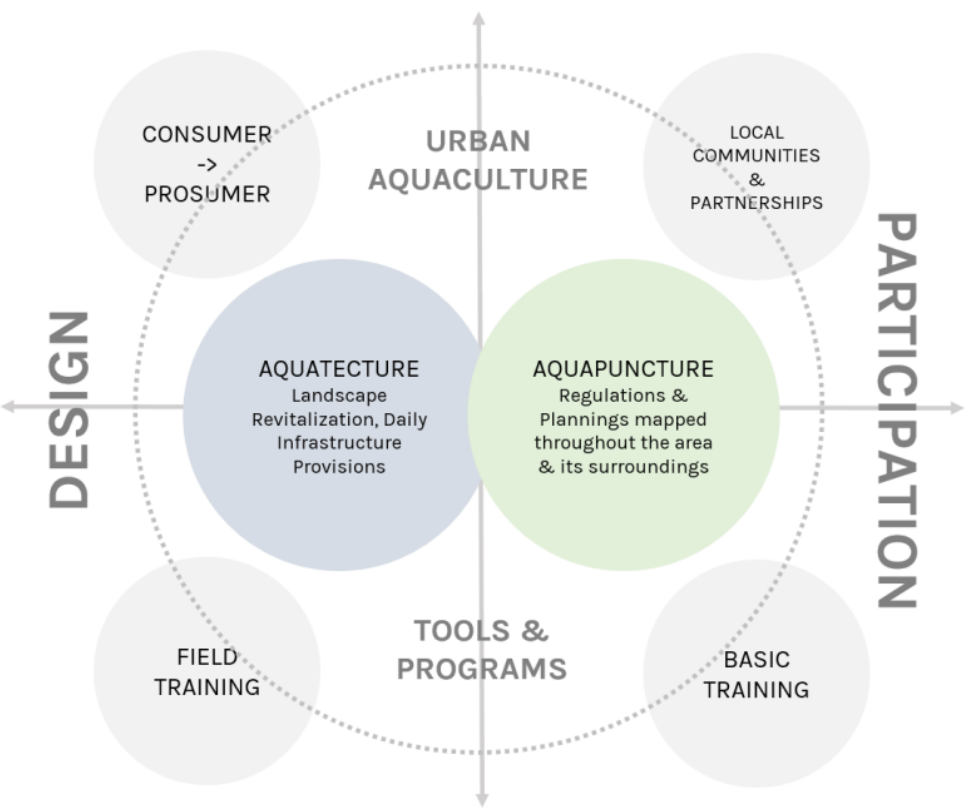

Figure 24. Suggested Framework for Future Research. Source: Team Analysis. 


\section{References}

Apud F, Primavera JH, 1983. Farming of Prawns and Shrimps, SEAFDEC Extension Manual No. 5. ISSN 0115-5369; http://hdl.handle.net/10862/1492

Bürgow, Grit. 2014. Urban Aquaculture: Water-sensitive transformation of cityscapes via blue-green infrastructures. Berlin.

Cameron, A. 2002. Survey Toolbox for Aquatic Animal Diseases. A Practical Manual and Software Package. ACIAR Monograph No. 94, 375p.

Eijk, P van \& Kumar, R. 2009. Bio-rights in theory and practice. A financing mechanism for linking poverty alleviation and environmental conservation. Wetlands International, Wageningen, The Netherlands.

Ezban, M. 2020. Aquaculture Landscapes: Fish Farms and The Public Realm. Routledge. New York. USA.

Heriyanto, Ade. 2016. Pemberdayaan Ekonomi Masyarakat Nelayan Desa Karangsong di Kecamatan Indramayu Kabupaten Indramayu. Universitas Pendidikan Indonesia.

Hilbrands, A. \& Yzerman, C. 2004. On-farm fish culture. Agrodok 21. Agromisa Foundation Wageningen. https://publications.cta.int/media/publications/downloads/863 PDF 1.pdf

Hoyer, J., Dickhaut, W., Kronawitter, L., Weber, B. 2011. Water Sensitive Urban Design - Principles and Inspiration for Sustainable Stormwater Management in the City of the Future. Hamburg.

KKP. 2013. Pengembangan Kawasan Minapolitan. Jakarta: KKP (Kementerian Kelautan dan Perikanan).

Muarif et al. 2019. IOP Conf. Ser.: Earth Environ. Sci. 383012033.

Omat, Soetomo S, Ma'rif S. 2008. Implikasi keberadaan PPI terhadap pertumbuhan kawasan ekonomi perikanan (studi kasus: PPI Karangsong Kecamatan Indramayu Provinsi Jawa Barat). Volume ke-4.

Tedi, Nahraeni W, Muarif. 2020. Analisis Kelayakan Finansial Tambak Ikan Bandeng Sistem Silvoakuakultur. J. Mina Sains. 6(1):40-47.

Wetland International. 2020. Building With Nature: Associated Mangrove Aquaculture Farms- Building with Nature to Restore Eroding Tropical Muddy Coasts. Ecoshape Technical Report, Dordrecht, The Netherlands. 